Research Paper

\title{
Indoxyl Sulfate-induced Vascular Calcification is mediated through Altered Notch Signaling Pathway in Vascular Smooth Muscle Cells
}

Kazutoshi Yamaguchi ${ }^{1}$, Maimaiti Yisireyili1 ${ }^{1}$, Sumie Goto ${ }^{2}$, Katsuhiro Kato ${ }^{1}$, Xian Wu Cheng ${ }^{3,4}$, Takayuki Nakayama ${ }^{5}$, Tadashi Matsushita6,7, Toshimitsu Niwa ${ }^{8}$, Toyoaki Murohara ${ }^{1}$, Kyosuke Takeshita ${ }^{1,6,9}{ }^{\bowtie}$

1. Department of Cardiology, Nagoya University Graduate School of Medicine, Nagoya, Japan.

2. Biomedical Research Laboratories, Kureha Co., Tokyo, Japan.

3. Department of Cardiology/Hypertension and Heart Center, Yanbian University Hospital, Yanji, Jilin, China.

4. Department of Community Health and Geriatrics, Nagoya University Graduate School of Medicine, Nagoya, Japan.

5. Department of Blood Transfusion, Aichi Medical University Hospital, Nagakute, Japan.

6. Department of Clinical Laboratory, Nagoya University Hospital, Nagoya, Japan.

7. Department of Blood Transfusion, Nagoya University Hospital, Nagoya, Japan.

8. Shubun University, Ichinomiya, Aichi, Japan.

9. Department of Clinical Laboratory, Saitama Medical Centre, Saitama Medical University, Kawagoe, Japan.

$\triangle$ Corresponding author: Prof. Kyosuke Takeshita, MD, PhD, FAHA. Department of Clinical Laboratory, Saitama Medical Centre, Saitama Medical University, 1981 Kamoda Kawagoe, Saitama, Japan. Tel: +81 52744 2147; Fax: +81 52744 2138. E-mail: kyousuke@saitama-med.ac.jp.

(C) The author(s). This is an open access article distributed under the terms of the Creative Commons Attribution License (https://creativecommons.org/licenses/by/4.0/). See http://ivyspring.com/terms for full terms and conditions.

Received: 2019.12.18; Accepted: 2020.08.31; Published: 2020.09.23

\begin{abstract}
Introduction: The aim of this study was to determine the role of Notch in indoxyl sulfate (IS)-induced vascular calcification (VC).

Materials and methods: VC and expression of Notch-related and osteogenic molecules were examined in Dahl salt-sensitive (DS), DS hypertensive (DH), and DH IS-treated rats (DH+IS). The effects of IS on expression of Notch receptors, apoptotic activity, and calcification were examined in cultured aortic smooth muscle cells (SMCs).

Results: Medial calcification was noted only in aortas and coronary arteries of DH+IS rats. Notch 1 , Notch3, and Hes-1 were expressed in aortic SMCs of all rats, but only weakly in the central areas of the media and around the calcified lesions in DH+IS rats. RT-PCR and western blotting of DH+IS rat aortas showed downregulation of Notch ligands, Notchl and Notch3, downstream transcriptional factors, and SM22, and conversely, overexpression of osteogenic markers. Expression of Notch1 and Notch3 in aortic SMCs was highest in incubation under $500 \mu \mathrm{M}$ IS for $24 \mathrm{hrs}$, and then decreased time- and dose-dependently. Coupled with this decrease, IS increased caspase 3/7 activity and TUNEL-positive aortic SMCs. In addition, pharmacological Notch signal inhibition with DAPT induced apoptosis in aortic SMCs. ZVAD, a caspase inhibitor abrogated IS-induced and DAPT-induced in vitro vascular calcification. Knockdown of Notchl and Notch3 cooperatively increased expression of osteogenic transcriptional factors and decreased expression of SM22.
\end{abstract}

Conclusion: Our results suggested that IS-induced VC is mediated through suppression of Notch activity in aortic SMCs, induction of osteogenic differentiation and apoptosis.

Key words: keyword 1 indoxyl sulfate; keyword 2 vascular calcification; keyword 3 Notch signal.

\section{Introduction}

Indoxyl sulfate (IS) is a protein-bound uremic toxin, produced from metabolic conversion of dietary tryptophan, with vascular toxicity. Deterioration of renal dysfunction in chronic kidney disease (CKD) ultimately results in accumulation of IS. IS affects various signal pathways, such as those associated with oxidative stress, inflammation, cellular phenotype, and cell survival in vascular smooth 
muscle cells (VSMCs), and enhances vascular calcification (VC) [1]. The cardiovascular mortality and morbidity rates are higher in patients with CKD compared with those of the general population [1]. The severity of abdominal aortic calcification is associated with high risk of cardiovascular morbidity and mortality based on the high potential of cardiovascular events in patients with CKD [2]. In patients with $\mathrm{CKD}$, high IS plasma levels correlate with the progression of carotid artery atherosclerosis and cardiovascular events [3]. Thus, it seems that IS is a risk factor for cardiovascular events in patients with CKD by inducing vascular injury and severe VC.

Notch signaling is a highly conserved signaling pathway associated with cellular activity, survival and differentiation [4]. Notch receptors (Notch1-4) and their ligands (Jagged1-2 and Delta-like-1,3,4) are families of transmembrane proteins with large extracellular domains [5]. Interaction of Notch receptors with membrane-bound ligands on the surface of neighboring cells leads to $\mathrm{Y}$-secretase-dependent cleavage of the Notch intracellular domain (NICD) [5-7]. These events result in the release of NICD into the nucleus, which interacts with the RBP-J protein, and the resultant complex functions as a transcription factor for various downstream target genes, such as hairy enhancer of split homolog-1 (Hes-1) and Hairy/enhancer-of-split related with YRPW motif protein 1 (Hey-1) [8] [9]. Notch1 and 3 receptors are highly expressed in VSMCs, and Notch1, rather than Notch3, mediates VSMC proliferation, migration and neointimal formation following vascular injury [8]. In human atherosclerotic lesions, Notch1 is also highly expressed in the VSMCs in the media [10]. Various inflammatory cytokines, such as interlukin- $1 \beta$ and tumor necrosis factors, increase the expression levels of Notch receptors, ligands, and downstream transcriptional factors to activate Notch signaling [11]. On the other hand, IS-related cytotoxicity can alter Notch signal activity through various inflammatory mediators and reactive oxygen species [12].

VSMCs differentiate into osteoblast-like cells to mediate the deposition of bone matrix in the vascular wall [13]. Bone-related transcriptional factors, such as Msx2, Sox9, and Runx2, which upregulate bone and chondrocyte proteins, have been detected in the calcified lesions on the vascular wall [13]. These transcription factors regulate key processes important for osteoblast differentiation. Notch signaling is likely to be involved in this process based on its pleiotropic effects to determine cell fate. Notch target genes, Hes-1 and Hey-1, suppress Runx2 to inhibit osteoblastic differentiation [14]. Conversely, pharmacological inhibition of Notch signaling or decrease in Notch signal activity induced by cell senescence, promotes osteogenic differentiation in cultured stromal cells [15]. Apoptosis of VSMCs also plays a critical role in VC since apoptotic bodies released from VSMCs, as well as matrix vesicles, can concentrate and crystalize calcium and phosphate in the process of mineralization [13]. As described above, Notch signaling also plays critical roles in cell survival. Haploinsufficiency of Notch1 promotes apoptosis of VSMCs in ex vivo culture conditions and murine models of vascular injury [8]. Furthermore, loss-of-function mutation in Notch1 promotes VSMC apoptosis [16] and severe valve calcification with derepressed Runx2 transcriptional activity [17]. Conversely, overexpression of Notch1 and Notch3 in rat VSMCs resulted in a significant decrease in cell apoptosis in association with a decrease in the BAX:BCL-xL mRNA expression ratio [16]. Thus, IS-induced modulation of Notch signal activity is likely to be involved in VC.

The aim of the present study was to determine the role of Notch signaling in IS-induced VC. Specifically, we investigated the effects of IS accumulation on Notch1 signaling in VSMCs of Dahl salt-sensitive normotensive rats (DS), Dahl salt-sensitive hypertensive control rats $(\mathrm{DH})$, and Dahl salt-sensitive hypertensive IS-administered rats (DH+IS) [18]. We also examined the relationship between VC and expression of Notch-related molecules. Furthermore, we examined IS-induced decline in Notch signal activity and its effects on vascular calcification via apoptosis and differentiation in cultured VSMCs. The results showed that IS reduced Notch signal activity to induce calcification via apoptotic body formation and osteogenic differentiation.

\section{Materials and Methods}

\section{Animal Studies}

Experimental rats were prepared as reported previously [18]. Briefly, five-week-old Dahl salt-sensitive rats (Dahl-Iwai $S(D S), n=24$ ) were purchased from Japan SLC, Inc. (Hamamatsu, Shizuoka, Japan), and fed powder rat chow (CE-2, Clea, Tokyo, Japan) for 1 week. Then, six of DS rats were fed chow (CE-2) with low-salt $(0.3 \% \mathrm{NaCl})$ intake in water, while another group of 24 were fed chow (CE-2) with high-salt $(2.0 \% \mathrm{NaCl})$ intake in water. At 7 weeks of age, the latter group of DS rats developed spontaneous hypertension with systolic blood pressure (BP) of more than $140 \mathrm{mmHg}$. The spontaneously hypertensive rats were divided into two groups: control rats and IS-administered rats. Thus, the rat groups used in this study consisted of (i) 
Dahl salt-sensitive normotensive rats (DS, $\mathrm{n}=6$ ) with intake of $0.3 \% \mathrm{NaCl}$ in water, (ii) Dahl salt-sensitive hypertensive control rats $(\mathrm{DH}, \mathrm{n}=12)$ with intake of $2.0 \% \mathrm{NaCl}$ in water, (iii) Dahl salt-sensitive hypertensive IS-administered rats $(\mathrm{DH}+\mathrm{IS}, \mathrm{n}=12$ ) with intake of $2.0 \% \mathrm{NaCl}$ and $200 \mathrm{mg} / \mathrm{kg}$ of IS (Alfa Aesar, Lancashire, UK) in water, for 30 weeks. Blood pressure was measured at the tail using a pneumatic cuff and a sphygmomanometer for small animals (UR-5000, Ueda Avancer Co., Tokyo, Japan) [18]. Creatinine and BUN levels were measured using a Beckman Synchron CX3 auto-analyzer [18]. Serum IS levels were measured by high-performance liquid chromatography, using the method reported in detail previously [19]. Serum calcium and phosphate levels, and lipid profiles were measured by standard methods $[7,18,20]$.

\section{Reagents}

The following reagents and antibodies were used in the present study: anti-DLL4, anti-Hes-1, and anti-Hey-1 (Abcam, Cambridge, UK), anti-Jagged1, anti-Notch1, and anti-Notch3 antibodies (Santa Cruz Biotechnology, Santa Cruz, CA), anti- $\beta$ actin (Calbiochem, La Jolla, CA), anti-rabbit IgG horseradish peroxidase (HRP)-linked antibody and anti-mouse IgG HRP-linked antibody (Cell Signalling Technology, Beverly, MA). H\&E staining kit and von Kossa staining kit were purchased from Abcam (Cambridge, UK). Human aortic SMCs were purchased from Cascade Biologics (Portland, OR). Rat aortic SMCs were purchased from Cell Applications Inc. (San Diego, CA). Dulbecco's modified Eagle's medium (D-MEM), fetal bovine serum (FBS), penicillin-streptomycin, and trypsin-EDTA solutions were purchased from Gibco (Invitrogen, Grand Island, NY). IS was purchased from Sigma Chemical (St. Louis, MO). Calcium deposition detection kit was purchased from Wako (Osaka, Japan).

\section{Histological and immunohistochemical analyses}

Aortic and cardiac sections were processed into $5-\mu \mathrm{m}$ thick sections and stained with H\&E and von-Kossa staining, using standard histological procedures [21]. Immunohistochemistry was performed according to the streptavidin-biotinylated peroxidase complex method using standard protocols as described in detail previously [7, 20]. Aortic sections were processed and stained using anti-Notch1 antibody (dilution, 1:100), anti-Notch3 antibody (dilution, 1:100), and anti-Hes-1 antibody (dilution, 1:100).

\section{Quantitative real-time polymerase chain reaction ( $R T$ T-PCR)}

Total RNA extraction, reverse-transcription, and quantitative PCR were performed as described in detail previously [22]. The primer sequences used in this study are listed in Table 1.

Table 1. Sequences of primers used for RT-PCR.

\begin{tabular}{|c|c|c|}
\hline & Forward $\left(5^{\prime}-3^{\prime}\right)$ & Reverse (5'-3') \\
\hline R Jagged1 & CATCGAGAAACACGGAGC & $\begin{array}{l}\text { TATCCATATCATCCTCTTCCACT } \\
\text { T }\end{array}$ \\
\hline R Dll4 & TGCGGATAACCAACGACG & CCCACAAAGCCATAAGGAC \\
\hline R Notch1 & $\begin{array}{l}\text { GGTGCGAGCGCAGTGAAGG } \\
\text { A }\end{array}$ & CCCGCTGCTGCCCTCTTTCC \\
\hline R Notch3 & AGCGAGCATCCTTATTTGAC & TTGCTGGACTAGGCGTT \\
\hline R Hes-1 & GCTGCTACCCCAGCCAGTG & $\begin{array}{l}\text { GCCTCTTCTCCATGATAGGCTT } \\
\text { TG }\end{array}$ \\
\hline R Hey-1 & $\begin{array}{l}\text { AGTGAGCTGGACGAGACCA } \\
\mathrm{T}\end{array}$ & CTGGGTACCAGCCTTCTCAG \\
\hline R RUNX2 & $\begin{array}{l}\text { TCATTCAGTGACACCACCAG } \\
\text { G }\end{array}$ & TGTAGGGGCTAAAGGCAAAA \\
\hline R OPN & $\begin{array}{l}\text { CCCATCTCAGAAGCAGAATC } \\
\text { TT }\end{array}$ & GTCATGGCTTTCATTGGAGTTG \\
\hline $\mathrm{ROCN}$ & $\begin{array}{l}\text { GACAAGTCCCACACAGCAA } \\
\text { C }\end{array}$ & GGACATGAAGGCTTTGTCAGA \\
\hline R ALP & GAGATGGTATGGGCGTCTC & GTTGGTGTTGTACGTCTTGGA \\
\hline R OsX & $\begin{array}{l}\text { AGAAGCCATACACTGACCTT } \\
\text { TC }\end{array}$ & GGTGGGTAGTCATTGGCATAG \\
\hline R MSX1 & TGACTTCTTTGCCACTCGGTG & CTATGTCAGGTGGTACATGCTG \\
\hline R MSX2 & $\begin{array}{l}\text { CCTCGGTCAAGTCGGAAAAT } \\
\text { TC }\end{array}$ & CGTATATGGATGCTGCTTGCAG \\
\hline R BMPs2 & TGAACACAGCTGGTCTCAGG & ACCCCACATCACTGAAGTCC \\
\hline R SM22 & CACTGGGCAAAGATGACT & ССАСТTСТСССТGСТTАСТС \\
\hline $\mathrm{R} \beta$-actin & $\begin{array}{l}\text { CTAAGGCCAACCGTGAAAA } \\
\text { G }\end{array}$ & TACATGGCTGGGGTGTTGA \\
\hline H Notch1 & ATCCTGATCCGGAACCGAG & CGTCGTGCCATCATGCAT \\
\hline H Notch3 & $\begin{array}{l}\text { TTTGAGGGTCAGAATTGTGA } \\
\text { AGTG }\end{array}$ & TCGGTGTCCTGGACAGTCG \\
\hline $\mathrm{H} \beta$-actin & $\begin{array}{l}\text { AGAAAATCTGGCACCACAC } \\
\text { C }\end{array}$ & GTCTCAAACATGATCTGGG \\
\hline
\end{tabular}

\section{Western blot analysis}

Equal amounts of rat aorta samples $(30 \mathrm{mg})$ from the rats of each group were homogenized and total protein concentration was measured using the Pierce BCA Protein Assay Kit (Thermo Scientific Inc., Billerica, MA). VSMCs were lysed in lysis buffer (65 mmol/L Tris- $\mathrm{HCl}$ ( $\mathrm{pH}$ 6.8), 3.3\% sodium dodecyl sulfate (SDS), $10 \%$ glycerol, $2.2 \%$ bromophenol blue). $10 \mu \mathrm{g}$ of protein from the aorta homogenates and cultured cells were separated by SDS-polyacrylamide gel electrophoresis and transferred onto polyvinylidene difluoride (PVDF) membranes (Immobilon-P, Millipore Bedford, MA). The membranes were incubated with antibodies directed against rabbit polyclonal anti-Jagged1 antibody (dilution, 1:1000), rabbit polyclonal anti-DLL4 antibody (dilution, 1:1000), rabbit polyclonal anti-Notch1 antibody (dilution, 1:1000), rabbit polyclonal anti-Notch3 antibody (dilution, 1:1000), rabbit polyclonal anti-Hes-1 antibody (dilution, 1:2000), rabbit polyclonal anti-Hey-1 antibody (dilution, 1:1000), respectively. Then, the membranes 
were further incubated with HRP-linked secondary antibody (dilution, 1:10000) at room temperature for 1 hr. After washing with TBS-T three times, protein expression was visualized using the enhanced Chemi-Lumi one system (Nacalai Tesque, Kyoto, Japan). The intensity of protein bands was normalized to the amount of $\beta$-actin (an internal control, dilution, 1:10000) and expressed as ratio (fold increase) of the control value.

\section{Cell Cultures}

Rat and human aortic SMCs were maintained in D-MEM containing 10\% FBS supplemented with 100 $\mathrm{U} / \mathrm{mL}$ penicillin and $100 \mu \mathrm{g} / \mathrm{mL}$ streptomycin at standard cell culture condition $\left(37^{\circ} \mathrm{C}\right.$ under $5 \% \mathrm{CO}_{2}$ humidified atmosphere). The medium was replaced every three days until confluence. Only cells between passages 2 to 8 were used for experiments. Rat and human aortic SMCs were incubated with 0-1000 $\mu \mathrm{mol} / \mathrm{L}$ of IS and $0-20 \mu \mathrm{mol} / \mathrm{L}$ of N-S-phenyl-glycine-t-butyl ester (DAPT), a Notch signal inhibitor, for the indicated time periods (IS: 0-96 hrs, DAPT: 0-72 hrs).

\section{TUNEL assay and caspase 3/7 activity assay}

Rat and human aortic SMCs were incubated with $0-1000 \mu \mathrm{mol} / \mathrm{L}$ of IS and $0-20 \mu \mathrm{mol} / \mathrm{L}$ of DAPT for the indicated time periods $(0-72 \mathrm{hrs})$. Apoptosis was examined by TUNEL assay, using the apoptosis detection TUNEL kit and Caspase 3/7 assay kit and the protocol supplied by the manufacturer (MK-500, Takara, Japan). In brief, cluttered samples were lysed with the assay buffer, and centrifuged at $15,000 \times g$ for $15 \mathrm{~min}$ at $4^{\circ} \mathrm{C}$. The supernatant was collected and used for the assay. TUNEL-positive cells were counted in 10 randomly representative fields under light microscopy.

\section{Measurement of calcium deposition in aortic SMCs}

Calcium deposition in human aortic SMCs was induced by inorganic phosphate $(3 \mathrm{mM})$ and examined as described in detail previously [23]. The cells were seeded at a density of $2 \times 10^{5}$ cells/well on 12 -well culture plate in D-MEM containing $10 \%$ FBS for 48 hour. The cells were pre-incubated with DAPT $(20 \mu \mathrm{M})$ and ZVAD $(100 \mu \mathrm{M})$ for $1 \mathrm{hr}$, then stimulated with $\mathrm{Pi}(3 \mathrm{mM})$ or IS $(1000 \mu \mathrm{M})$ for $72 \mathrm{hrs}$. Thereafter, the cultured cells were washed 3 times in ice cold PBS, then fixed with $70 \%$ ethanol at room temperature for 1 $\mathrm{hr}$, then treated with 5\% sliver nitrate under UV light for $45 \mathrm{~min}$. The culture plates were photographed under light microscopy $(\times 400)$ with digital camera (DN100, E-600, Nikon; Tokyo). Finally, the plates were washed with distilled water, and then decalcified with $0.6 \mathrm{~N} \mathrm{HCl}$ for $12 \mathrm{hrs}$, and then standards and assay buffers were added to the plates. Absorbance was measured at 570-650 nm using a microplate reader (DS Pharmacy Biomedical Co., Osaka). The values were corrected by the amount of total protein. Total protein concentration was measured using the Pierce BCA Protein Assay Kit.

\section{SiRNA transfection of aortic SMCs}

The siRNA oligo targeting Notch1 (catalog no. s129952), Notch3 (catalog no. s132728) and negative control were purchased from Thermo Fisher Scientific (Waltham, MA). We transfected siRNA to the rat aortic SMCs according to the instruction manual of Lipofectamine RNAiMAX (Thermo Fisher Scientific).

\section{Statistical analysis}

Data are expressed as mean $\pm S D$. Differences between groups were assessed by the Student's t-test. Differences in the quantitative data among groups were analyzed by Fisher's protected least significant differences (PLSD) test of one-way analysis of variances (ANOVA). Results were considered significant when $\mathrm{P}<0.05$.

\section{Results}

\section{Laboratory parameters of DS, DH, and DH+IS rats.}

Table 2 summarizes the serial changes in several laboratory parameters in the DS, DH, and DH+IS rats throughout the 32-week study. Systolic blood pressure $(\mathrm{BP})$ in the $\mathrm{DH}$ and $\mathrm{DH}+\mathrm{IS}$ rats was significantly higher than DS rats, but similar between $\mathrm{DH}$ and DH+IS rats. Serum and urine levels of IS were significantly higher in DH+IS rats than in the other groups. However, there were no significant differences in blood urea nitrogen (BUN), serum creatinine, serum calcium $(\mathrm{Ca})$, serum phosphate $(\mathrm{P})$, calcium phosphorus product, and serum lipid profile among the groups.

\section{IS promotes aortic calcification in hypertensive rats.}

Figure 1 shows medial calcific sclerosis in both the aortic arch and coronary arteries of DH+IS rats [18]. These changes are similar to those observed in patients with Mönckeberg's arteriosclerosis [24]. No calcified lesions were observed in the other groups.

\section{IS alters the expression of Notch receptors and Hes- 1 in aortic SMCs.}

Immunohistochemistry for Notch1, Notch3 and Hes-1 was applied to assess the expression of Notch receptors and Notch-related molecules, (Figure 2). Overexpression of Notch1 (Figure 2a), Notch3 (Figure $2 \mathrm{~b}$ ), and Hes-1 (Figure 2c) was noted in aortic SMCs 
from the DS and DH rats. However, the expression levels of these molecules were lower in aortic SMCs obtained from the central layer of the aortic media of DH+IS rats. Notably, signals for these molecules were hardly observed in the calcified lesions of DH+IS rats.

\section{IS reduces expression levels of Notch-related molecules in aorta.}

Next, we used quantitative RT-PCR to determine the expression levels of Notch ligands (Jagged1 and DLL4; Figure 3a and b), Notch receptors (Notch1 and Notch3; Figure $3 c$ and $d$ ), and downstream transcriptional factors (Hes-1 and Hey-1; Figure 3e and f). In agreement with the results of immunohistochemistry (Figure 2), the mRNA expression levels of Notch-related molecules were lower in the aortas of the DH+IS rats, compared with the other groups. The results of western blot analysis shown in Figure $3 \mathrm{~g}$ also demonstrated lower protein levels of Notch-related molecules in the aortas of the DS+IS rats.

\section{Involvement of IS in differentiation of aortic VSMCs into osteoblast-like phenotype.}

To determine the role of IS in the differentiation of aortic SMCs into an osteoblast-like phenotype, we analyzed the expression levels of bone-related transcriptional factors by RT-PCR. Figure 4 shows significantly higher mRNA expression levels of RUNX2, OPN, OCN, ALP, OSX, MSX1, MSX2, and BMPs2 in DH+IS rats, compared with the other groups. In contrast, the mRNA expression levels of SM22, a VSMC differentiation marker, was lower in $\mathrm{DH}+\mathrm{IS}$ rats.

Table 2. Time course of laboratory parameters in DS, DH and DH+IS rats.

\begin{tabular}{|c|c|c|c|c|c|c|c|c|c|c|c|c|c|c|c|}
\hline & DS & & & & & DH & & & & & $\mathrm{DH}+\mathrm{IS}$ & & & & \\
\hline & $0 \mathrm{w}$ & $8 w$ & $16 \mathrm{w}$ & $24 \mathrm{w}$ & $32 \mathrm{w}$ & $0 w$ & $8 w$ & $16 \mathrm{w}$ & $24 \mathrm{w}$ & $32 \mathrm{w}$ & $0 \mathrm{w}$ & $8 w$ & $16 \mathrm{w}$ & $24 \mathrm{w}$ & $32 \mathrm{w}$ \\
\hline$n$ & 6 & 6 & 6 & 6 & 6 & 12 & 12 & 12 & 12 & 12 & 12 & 12 & 12 & 12 & 12 \\
\hline BW (g) & $\begin{array}{l}189.9 \pm \\
9.7\end{array}$ & $\begin{array}{l}412.4 \pm \\
15.9\end{array}$ & $\begin{array}{l}466.4 \pm \\
15.5\end{array}$ & $\begin{array}{l}496.1 \pm \\
15.2\end{array}$ & $\begin{array}{l}516.6 \pm \\
16.5\end{array}$ & $\begin{array}{l}182.5 \pm \\
4.8\end{array}$ & $\begin{array}{l}376.8 \pm \\
13.4^{\mathrm{d}}\end{array}$ & $\begin{array}{l}414.4 \pm \\
16.5^{\mathrm{d}}\end{array}$ & $\begin{array}{l}439.6 \pm \\
15.6^{\mathrm{d}}\end{array}$ & $\begin{array}{l}443 \pm \\
24.2^{\mathrm{d}}\end{array}$ & $\begin{array}{l}181.7 \pm \\
5\end{array}$ & $\begin{array}{l}367.4 \pm \\
16.7^{\mathrm{d}}\end{array}$ & $\begin{array}{l}405.9 \pm \\
16.5^{\mathrm{d}}\end{array}$ & $\begin{array}{l}428.2 \pm \\
16.4^{\mathrm{d}}\end{array}$ & $\begin{array}{l}437.2 \pm \\
18.9^{\mathrm{d}}\end{array}$ \\
\hline $\begin{array}{l}\text { Systolic BP } \\
(\mathrm{mmHg})\end{array}$ & $\begin{array}{l}127.1 \pm \\
5.9\end{array}$ & $\begin{array}{l}138.4 \pm \\
6.7\end{array}$ & $\begin{array}{l}132.3 \pm \\
9.2\end{array}$ & $\begin{array}{l}140.8 \pm \\
10.2\end{array}$ & $\begin{array}{l}133.7 \pm \\
7.4\end{array}$ & $\begin{array}{l}130.5 \pm \\
5.9\end{array}$ & $\begin{array}{l}148.2 \pm \\
16.7\end{array}$ & $\begin{array}{l}158.1 \pm \\
13.7^{c}\end{array}$ & $\begin{array}{l}159.1 \pm \\
20.5\end{array}$ & $\begin{array}{l}160.3 \pm \\
17.8^{c}\end{array}$ & $\begin{array}{l}132.4 \pm \\
12.3\end{array}$ & $\begin{array}{l}146.1 \pm \\
9.6\end{array}$ & $\begin{array}{l}150.4 \pm \\
15^{a}\end{array}$ & $\begin{array}{l}146.3 \pm \\
17.7\end{array}$ & $\begin{array}{l}156.2 \pm \\
16.3^{\mathrm{b}}\end{array}$ \\
\hline $\mathrm{HR}(/ \mathrm{min})$ & $\begin{array}{l}431.6 \pm \\
24\end{array}$ & $\begin{array}{l}365.7 \pm \\
23.6\end{array}$ & $\begin{array}{l}377.8 \pm \\
33.1\end{array}$ & $\begin{array}{l}362.5 \pm \\
28.3\end{array}$ & $\begin{array}{l}358.7 \pm \\
24.1\end{array}$ & $\begin{array}{l}425.3 \pm \\
17\end{array}$ & $\begin{array}{l}377.2 \pm \\
44.1\end{array}$ & $\begin{array}{l}363.5 \pm \\
12\end{array}$ & $\begin{array}{l}360 \pm \\
27.3\end{array}$ & $\begin{array}{l}391 \pm \\
35.6\end{array}$ & $\begin{array}{l}424.9 \pm \\
18.3\end{array}$ & $\begin{array}{l}394.2 \pm \\
37.1\end{array}$ & $\begin{array}{l}376.4 \pm \\
24.4\end{array}$ & $\begin{array}{l}359.4 \pm \\
34\end{array}$ & $\begin{array}{l}387.3 \pm \\
32\end{array}$ \\
\hline S-IS (mg/dL) & $\begin{array}{l}0.183 \pm \\
0.06\end{array}$ & $\begin{array}{l}0.09 \pm \\
0\end{array}$ & $\begin{array}{l}0.059 \pm \\
0.01\end{array}$ & $\begin{array}{l}0.066 \pm \\
0.02\end{array}$ & $\begin{array}{l}0.084 \pm \\
0.02\end{array}$ & $\begin{array}{l}0.152 \pm \\
0.06\end{array}$ & $\begin{array}{l}0.08 \pm \\
0\end{array}$ & $\begin{array}{l}0.091 \pm \\
0.02\end{array}$ & $\begin{array}{l}0.082 \pm \\
0.02\end{array}$ & $\begin{array}{l}0.142 \pm \\
0.19\end{array}$ & $\begin{array}{l}0.167 \pm \\
0.06\end{array}$ & $\begin{array}{l}0.63 \pm \\
0.3 c e\end{array}$ & $\begin{array}{l}1.087 \pm \\
0.55^{\text {d.e }}\end{array}$ & $\begin{array}{l}1.235 \pm \\
0.33 \mathrm{dff}\end{array}$ & $\begin{array}{l}1.533 \pm \\
0.39 \mathrm{~d}, \mathrm{f}\end{array}$ \\
\hline BUN (mg/dL) & $\begin{array}{l}18.4 \pm \\
1.5\end{array}$ & $\begin{array}{l}20.1 \pm \\
2\end{array}$ & $\begin{array}{l}19.6 \pm \\
1.4\end{array}$ & $\begin{array}{l}20.3 \pm \\
1.1\end{array}$ & $\begin{array}{l}19.8 \pm \\
1.2\end{array}$ & $\begin{array}{l}17.8 \pm \\
1.2\end{array}$ & $\begin{array}{l}25.3 \pm \\
2.1\end{array}$ & $\begin{array}{l}21.9 \pm \\
1.2\end{array}$ & $\begin{array}{l}20.7 \pm \\
1.9\end{array}$ & $\begin{array}{l}19.3 \pm \\
3\end{array}$ & $\begin{array}{l}17.6 \pm \\
1.7\end{array}$ & $\begin{array}{l}25.9 \pm \\
3.1\end{array}$ & $\begin{array}{l}22.4 \pm \\
2.8^{\mathrm{b}}\end{array}$ & $\begin{array}{l}21.4 \pm \\
1.6\end{array}$ & $\begin{array}{l}19.8 \pm \\
1.6\end{array}$ \\
\hline $\mathrm{S}-\mathrm{Cr}(\mathrm{mg} / \mathrm{dL})$ & $\begin{array}{l}0.26 \pm \\
0.03\end{array}$ & $\begin{array}{l}0.28 \pm \\
0.03\end{array}$ & $\begin{array}{l}0.31 \pm \\
0.02\end{array}$ & $\begin{array}{l}0.39 \pm \\
0.02\end{array}$ & $\begin{array}{l}0.34 \pm \\
0.03\end{array}$ & $\begin{array}{l}0.23 \pm \\
0.02\end{array}$ & $\begin{array}{l}0.32 \pm \\
0.03^{\mathrm{a}}\end{array}$ & $\begin{array}{l}0.31 \pm \\
0.03\end{array}$ & $\begin{array}{l}0.34 \pm \\
0.044^{\mathrm{a}}\end{array}$ & $\begin{array}{l}0.36 \pm \\
0.07\end{array}$ & $\begin{array}{l}0.24 \pm \\
0.04\end{array}$ & $\begin{array}{l}0.30 \pm \\
0.03\end{array}$ & $\begin{array}{l}0.30 \pm \\
0.03\end{array}$ & $\begin{array}{l}0.33 \pm \\
0.03^{\mathrm{b}}\end{array}$ & $\begin{array}{l}0.34 \pm \\
0.03\end{array}$ \\
\hline $\mathrm{s}-\mathrm{Ca}(\mathrm{mg} / \mathrm{dL})$ & $\begin{array}{l}10 \pm \\
0.2\end{array}$ & $\begin{array}{l}9.8 \pm \\
0.1\end{array}$ & $\begin{array}{l}9.4 \pm \\
0.1\end{array}$ & $\begin{array}{l}9.4 \pm \\
0.1\end{array}$ & $\begin{array}{l}9.4 \pm \\
0.1\end{array}$ & $\begin{array}{l}10 \pm \\
0.3\end{array}$ & $\begin{array}{l}9.4^{\mathrm{I}} \\
0.1^{\mathrm{d}}\end{array}$ & $\begin{array}{l}9.7 \pm \\
0.1^{\mathrm{c}}\end{array}$ & $\begin{array}{l}9.2 \pm \\
0.1^{c}\end{array}$ & $\begin{array}{l}9.4 \pm \\
0.2\end{array}$ & $\begin{array}{l}9.9 \pm \\
0.1\end{array}$ & $\begin{array}{l}9.5^{\mathrm{d}} \\
0.1^{\mathrm{d}}\end{array}$ & $\begin{array}{l}10.2 \pm \\
0.2^{\mathrm{d}, \mathrm{f}}\end{array}$ & $\begin{array}{l}9.3 \pm \\
0.1^{\mathrm{b}}\end{array}$ & $\begin{array}{l}9.2 \pm \\
0.1^{c, e}\end{array}$ \\
\hline $\mathrm{s}-\mathrm{IP}(\mathrm{mg} / \mathrm{dL})$ & $\begin{array}{l}10.4 \pm \\
0.4\end{array}$ & $\begin{array}{l}7.6 \pm \\
0.3\end{array}$ & $\begin{array}{l}6.2 \pm \\
0.4\end{array}$ & $\begin{array}{l}6.0 \pm \\
0.1\end{array}$ & $\begin{array}{l}5.9 \pm \\
0.3\end{array}$ & $\begin{array}{l}10.1 \pm \\
0.6\end{array}$ & $\begin{array}{l}6.7 \pm \\
0.5^{c}\end{array}$ & $\begin{array}{l}6.3 \pm \\
0.2\end{array}$ & $\begin{array}{l}5.7 \pm \\
0.4^{c}\end{array}$ & $\begin{array}{l}5.6 \pm \\
0.2^{\mathrm{b}}\end{array}$ & $\begin{array}{l}9.8 \pm \\
0.6\end{array}$ & $\begin{array}{l}6.5 \pm \\
0.4^{\mathrm{d}}\end{array}$ & $\begin{array}{l}6.4 \pm \\
0.4\end{array}$ & $\begin{array}{l}5.8^{ \pm} \\
0.3^{\mathrm{b}}\end{array}$ & $\begin{array}{l}5.4 \pm \\
0.7\end{array}$ \\
\hline $\mathrm{Ca} \times \mathrm{P}$ & $\begin{array}{l}103.1 \pm \\
6.5\end{array}$ & $\begin{array}{l}74.7 \pm \\
3.3\end{array}$ & $\begin{array}{l}57.9 \pm \\
3.4\end{array}$ & $\begin{array}{l}56 \pm \\
0.6\end{array}$ & $\begin{array}{l}55.9 \pm \\
2.7\end{array}$ & $\begin{array}{l}101.1 \pm \\
6.3\end{array}$ & $\begin{array}{l}63 \pm \\
5.1^{\mathrm{c}}\end{array}$ & $\begin{array}{l}60.3 \pm \\
2.7\end{array}$ & $\begin{array}{l}52.5 \pm \\
3.6\end{array}$ & $\begin{array}{l}51.9 \pm \\
2.1^{\mathrm{b}}\end{array}$ & $\begin{array}{l}97.2 \pm \\
6.5\end{array}$ & $\begin{array}{l}61 \pm \\
4.4^{\mathrm{c}}\end{array}$ & $\begin{array}{l}64.6 \pm \\
5.1^{\mathrm{a}, e}\end{array}$ & $\begin{array}{l}53.3 \pm \\
2.8\end{array}$ & $\begin{array}{l}49.9 \pm \\
6.4^{\text {a }}\end{array}$ \\
\hline T-cho (mg/dL) & $\begin{array}{l}54 \pm \\
5\end{array}$ & $\begin{array}{l}57 \pm \\
3\end{array}$ & $\begin{array}{l}62 \pm \\
8\end{array}$ & $\begin{array}{l}75 \pm \\
15\end{array}$ & $\begin{array}{l}97 \pm \\
19\end{array}$ & $\begin{array}{l}52 \pm \\
3\end{array}$ & $\begin{array}{l}62 \pm \\
9 \mathrm{a}\end{array}$ & $\begin{array}{l}81 \pm \\
18\end{array}$ & $\begin{array}{l}109 \pm \\
34^{c}\end{array}$ & $\begin{array}{l}138 \pm \\
32\end{array}$ & $\begin{array}{l}53 \pm \\
3\end{array}$ & $\begin{array}{l}59 \pm \\
6\end{array}$ & $\begin{array}{l}75 \pm \\
11\end{array}$ & $\begin{array}{l}84 \pm \\
15\end{array}$ & $\begin{array}{l}111 \pm \\
27\end{array}$ \\
\hline HDL-c (mg/dL) & $\begin{array}{l}35.1 \pm \\
3.4\end{array}$ & $\begin{array}{l}35.4 \pm \\
1.1\end{array}$ & $\begin{array}{l}38.6 \pm \\
2.8\end{array}$ & $\begin{array}{l}44.7 \pm \\
4.6\end{array}$ & $\begin{array}{l}52.2 \pm \\
6.8\end{array}$ & $\begin{array}{l}36.4 \pm \\
1.9\end{array}$ & $\begin{array}{l}37.9 \pm \\
4.5^{c}\end{array}$ & $\begin{array}{l}48.5^{5} \\
11.4^{\mathrm{b}}\end{array}$ & $\begin{array}{l}54.5 \pm \\
16.2\end{array}$ & $\begin{array}{l}74.8 \pm \\
16.8^{\mathrm{a}}\end{array}$ & $\begin{array}{l}35.7 \pm \\
2.5\end{array}$ & $\begin{array}{l}36.4 \pm \\
2.8^{\mathrm{a}}\end{array}$ & $\begin{array}{l}46 \pm \\
6.4^{\text {a }}\end{array}$ & $\begin{array}{l}45.6 \pm \\
6.2\end{array}$ & $\begin{array}{l}62.4 \pm \\
12.5\end{array}$ \\
\hline TG (mg/dL) & $\begin{array}{l}118 \pm \\
20\end{array}$ & $\begin{array}{l}268 \pm \\
38\end{array}$ & $\begin{array}{l}248 \pm \\
64\end{array}$ & $\begin{array}{l}285 \pm \\
96\end{array}$ & $\begin{array}{l}372 \pm \\
171\end{array}$ & $\begin{array}{l}106 \pm \\
28\end{array}$ & $\begin{array}{l}241 \pm \\
42\end{array}$ & $\begin{array}{l}262 \pm \\
55\end{array}$ & $\begin{array}{l}466 \pm \\
129^{a}\end{array}$ & $\begin{array}{l}383 \pm \\
77\end{array}$ & $\begin{array}{l}118 \pm \\
22\end{array}$ & $\begin{array}{l}221 \pm 5 \\
7\end{array}$ & $\begin{array}{l}264 \pm \\
66\end{array}$ & $\begin{array}{l}315 \pm \\
83^{b}\end{array}$ & $\begin{array}{l}324 \pm \\
92\end{array}$ \\
\hline U-IS (mg/dL) & $\begin{array}{l}19.25 \pm \\
4.15\end{array}$ & $\begin{array}{l}12.86 \pm \\
4.36\end{array}$ & $\begin{array}{l}15.32 \pm \\
5.41\end{array}$ & $\begin{array}{l}10 \pm \\
3.24\end{array}$ & $\begin{array}{l}9.67 \pm \\
2.47\end{array}$ & $\begin{array}{l}16.98 \pm \\
5.53\end{array}$ & $\begin{array}{l}8.45 \pm \\
4.25^{b}\end{array}$ & $\begin{array}{l}5.4 \pm \\
1.5^{c}\end{array}$ & $\begin{array}{l}4.0 \pm \\
1.94\end{array}$ & $\begin{array}{l}5.5 \pm \\
3.9\end{array}$ & $\begin{array}{l}17.93 \pm \\
3.27\end{array}$ & $\begin{array}{l}136.17 \pm \\
20.98 \mathrm{~d}, \mathrm{f}\end{array}$ & $\begin{array}{l}135.11 \pm \\
28.76 \mathrm{~d}, \mathrm{f}\end{array}$ & $\begin{array}{l}100.77 \pm \\
6.89 \text { d.f }\end{array}$ & $\begin{array}{l}141.79 \pm \\
18.59 \mathrm{~d}, \hat{f}\end{array}$ \\
\hline $\mathrm{U}-\mathrm{Cr}(\mathrm{mg} / \mathrm{dL})$ & $\begin{array}{l}74.08 \pm \\
11.63\end{array}$ & $\begin{array}{l}80.39 \pm \\
19.18\end{array}$ & $\begin{array}{l}120.38 \pm \\
38.36\end{array}$ & $\begin{array}{l}109.04 \pm \\
42.39\end{array}$ & $\begin{array}{l}96.05 \pm \\
29.51\end{array}$ & $\begin{array}{l}76.88 \pm \\
12.23\end{array}$ & $\begin{array}{l}54.73 \pm \\
24.19 \mathrm{a}\end{array}$ & $\begin{array}{l}47.87 \pm \\
24.39\end{array}$ & $\begin{array}{l}43.43 \pm \\
21.86^{c}\end{array}$ & $\begin{array}{l}43.4 \pm \\
32.57 \mathrm{~b}\end{array}$ & $\begin{array}{l}72.27 \pm \\
16.62\end{array}$ & $\begin{array}{l}56.02+ \\
13.97 \mathrm{a}\end{array}$ & $\begin{array}{l}55.19 \pm \\
15.75^{b}\end{array}$ & $\begin{array}{l}44.37 \pm \\
13.42\end{array}$ & $\begin{array}{l}46.87 \pm \\
23.05^{b}\end{array}$ \\
\hline
\end{tabular}

Data are mean \pm SD. $\mathrm{aP}<0.05 ; \mathrm{bP}<0.01 ; \mathrm{cP}<0.001 ; \mathrm{dP}<0.0001$, compared with DS on the same week. eP $<0.01$, fP $<0.0001$ compared with DH on the same week [by Fisher's LSD test (ANOVA)].

DS: Dahl salt-sensitive rats, DH: Dahl salt-sensitive hypertensive control rats with an intake of $2.0 \% \mathrm{NaCl}$ in water, DH+IS: indoxyl sulfate-administered Dahl salt-sensitive hypertensive rats. BW: body weight, BP: blood pressure, S: serum, IS: indoxyl sulfate, BUN: blood urea nitrogen, Cr: creatinine, T-Cho: total cholesterol, HDL-C: high-density lipoprotein cholesterol, TG: triglyceride, U: urine. 
DS

a

$(\mathrm{H} \& \mathrm{E})$

(H\&)

b

(von-kossa)

c

(MT)
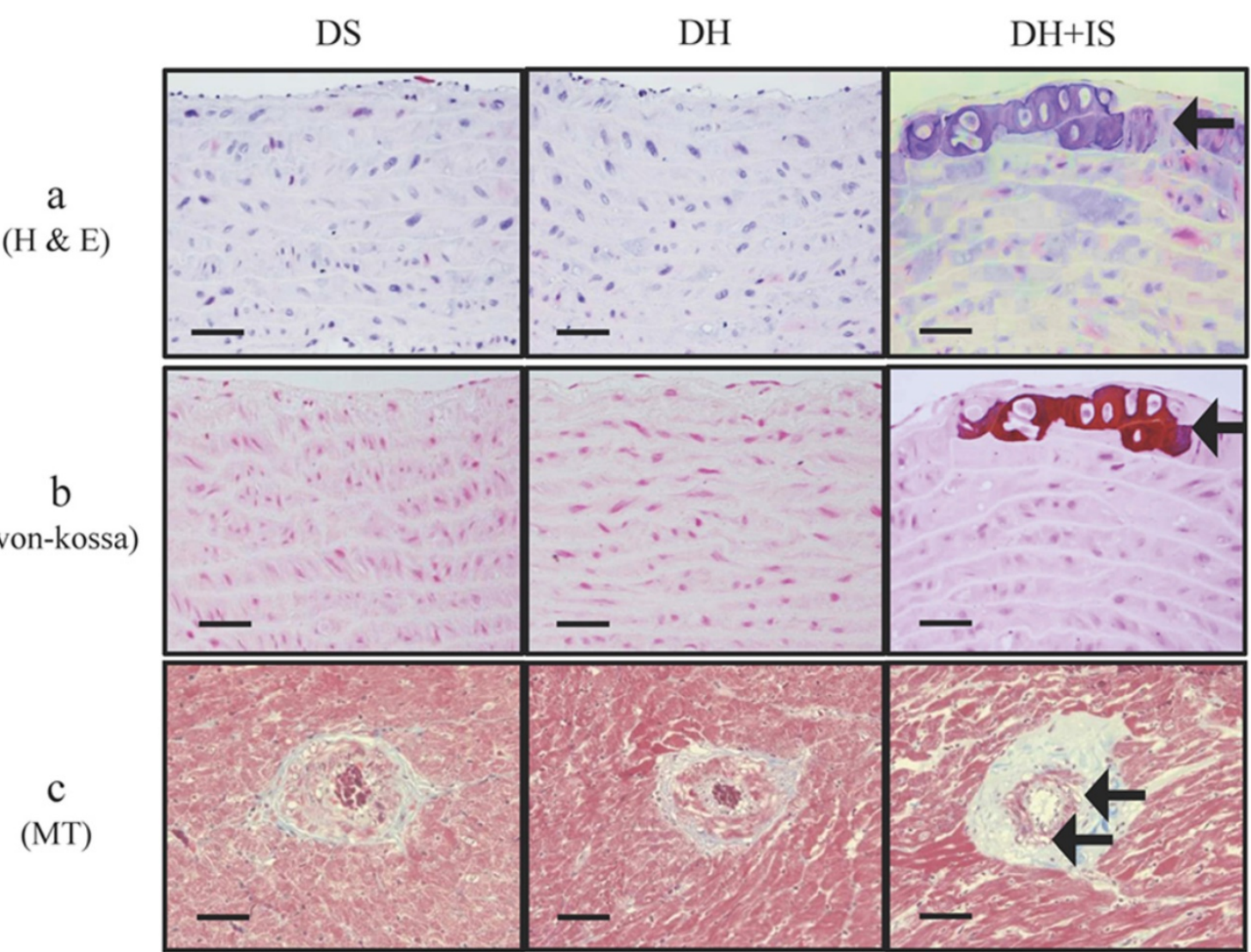

Figure 1. IS promotes calcification in aortas and coronary arteries of Dahl-hypertensive rats. H\&E staining (a) and von-Kossa staining (b) of aortas from DS, DH and $\mathrm{DH}+\mathrm{IS}$ rats. (c) Masson Trichrome staining (MT) of coronary arteries from DS, DH and DH+IS rat (c). $(\times 200$ magnification, bar=50 $\mu \mathrm{m})$. Arrows denote calcification.
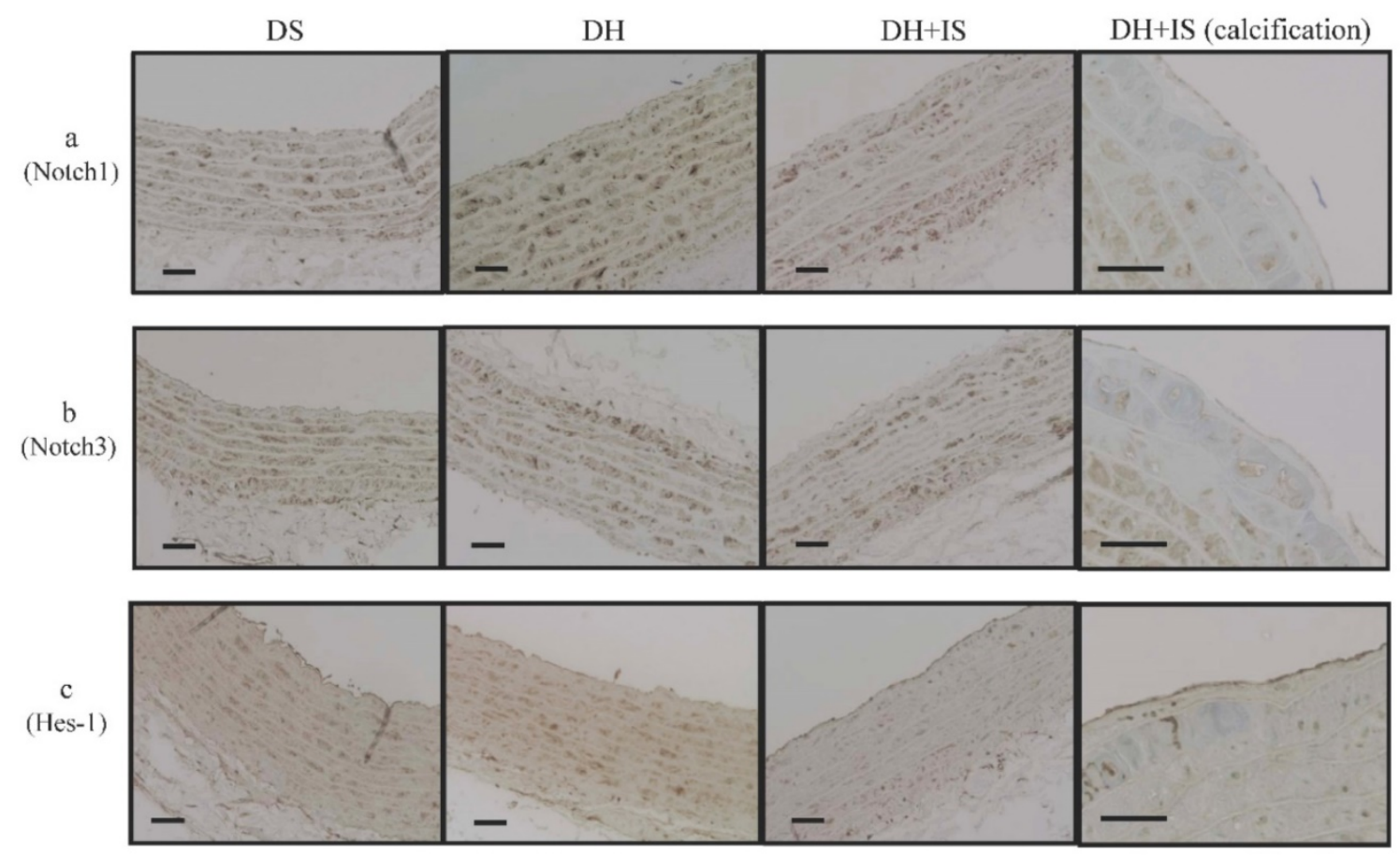

Figure 2. IS reduces Notch Signal activity in Dahl-hypertensive rats. Immunohistochemical analysis of Notchl (a), Notch3 (b), and Hes-1 (c) in the aortas of DS, DH, and $\mathrm{DH}+\mathrm{IS}$ rats $(\times 200$ magnification, bar $=50 \mu \mathrm{m})$, and calcification area of $\mathrm{DH}+\mathrm{IS}$ rats $(\times 400$ magnification, bar=50 $\mu \mathrm{m})$. 

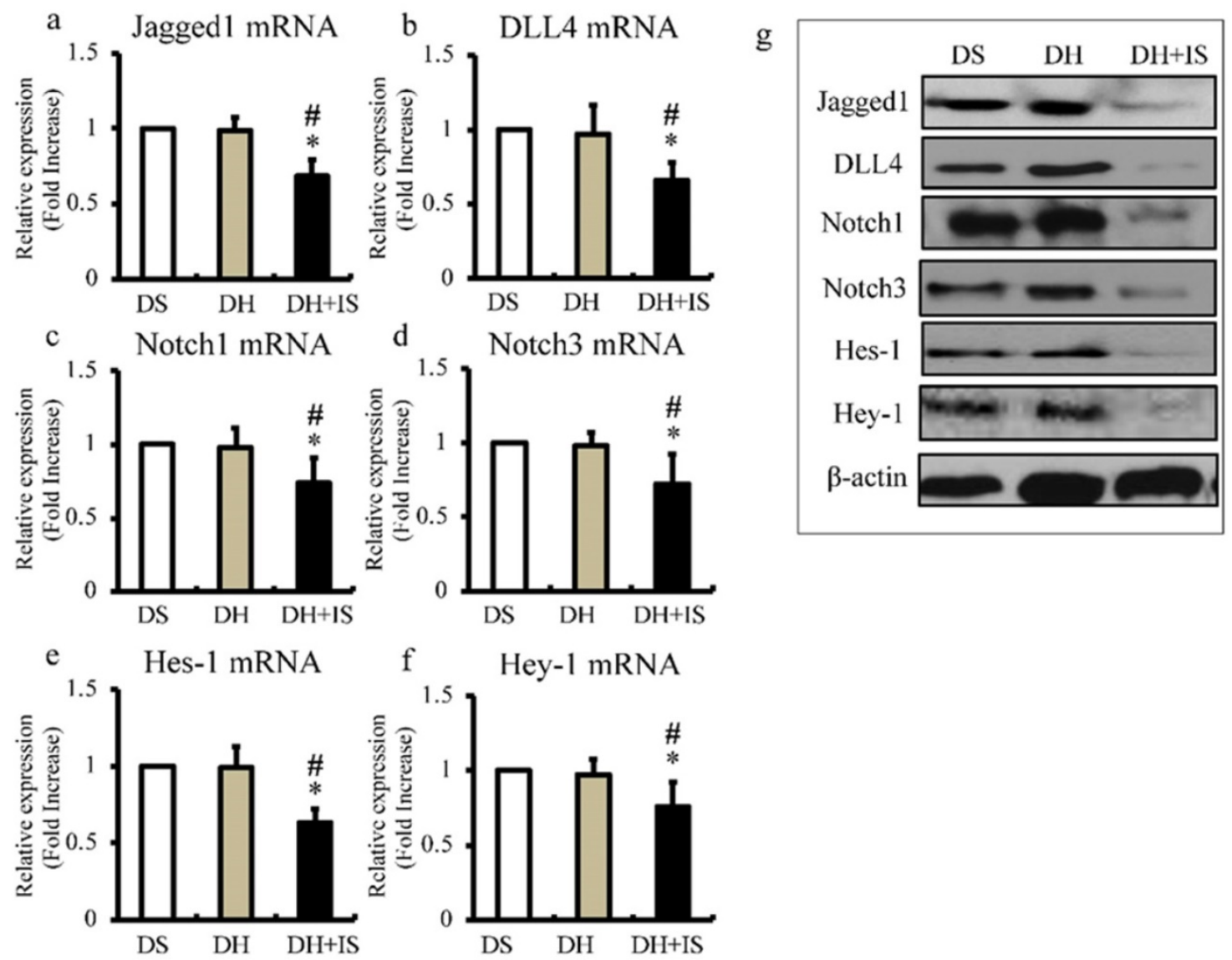

Figure 3. IS reduces the expression of Notch-related molecules in Dahl-hypertensive rats. Aortic mRNA and protein expression levels of Notch-related molecules in $\mathrm{DS}, \mathrm{DH}$, and $\mathrm{DH}+\mathrm{IS}$ rats were analyzed by quantitative RT-PCR and western blotting; respectively. Values are mean $\pm S D(n=6-8)$. (a) Quantitative analysis of Jagged $1 \mathrm{mRNA}$ expression in aortic tissue. ${ }^{*} \mathrm{p}<0.0001$ vs DS group, $\# \mathrm{p}<0.0001$ vs $\mathrm{DH}$ group. (b) Quantitative analysis of DLL4 mRNA expression in aortic tissue. ${ }^{*} \mathrm{p}<0.0007$ vs $\mathrm{DS}$ group, $\# p<0.001$ vs DH group. (c) Quantitative analysis of Notch 1 mRNA expression in aortic tissue *p $<0.005$ vs DS group, \#p $<0.007$ vs DH group. (d) Quantitative analysis of Notch3 mRNA expression in aortic tissue. ${ }^{*} p<0.001$ vs DS group, $\# p<0.003$ vs DH group. (e) Quantitative analysis of Hes-1 mRNA expression in aortic tissue. *p<0.0001 vs DS group, $\# p<0.0001$ vs DH group. (f) Quantitative analysis of Hey-1 mRNA expression in aortic tissue ${ }^{*} p<0.004$ vs DS group, \#p $<0.01$ vs DH group. (g) Expression levels of representative proteins Jagged1, DLL4, Notch1, Notch3, Hes-1, and Hey-1 in the aorta of DS, DH, and DH+IS rats.

\section{IS alters expression levels of Notch 1 and Notch3 in aortic SMCs}

We also examined the effects of different doses and duration of exposure to IS on the expression levels of Notch1 and Notch3 in cultured rat and human aortic SMCs by RT-PCR. The expression of Notch1 (Figure 5a) and Notch3 (Figure 5e) in rat aortic SMCs reached peak levels after $24 \mathrm{~h}$, and then decreased with time and exhibited significantly lower levels after 96h. Furthermore, the most significant increase and decrease in the expression levels of Notch1 (Figure 5b) and Notch3 (Figure 5f) in human aortic SMCs were noted at IS concentrations of 500 and $1000 \mu \mathrm{mol} / \mathrm{L}$, respectively. Western blot analysis also showed decreased expression of Notch1 (Figure 5c) and Notch3 (Figure 5g) in rat aortic SMCs after 96h after exposure to IS. In addition, the most significant increase and decrease in the expression of Notch1 (Figure 5d) and Notch3 (Figure 5h) in human aortic SMCs were noted at IS concentration of $500 \mu \mathrm{mol} / \mathrm{L}$ and $1000 \mu \mathrm{mol} / \mathrm{L}$.

\section{IS Induces apoptosis of aortic SMCs via Notch signal inhibition.}

Previous our studies showed that pharmacological inhibition of Notch signaling and Notch1 haploinsufficiency promote apoptosis [6] [8]. We examined the proapoptotic effect of pharmacological inhibition of Notch signaling with DAPT on apoptosis of rat aortic SMCs (Figure 6a-d). Consistent with our previous studies, DAPT significantly activated caspase $3 / 7$ activity in doseand time-dependent manners (Figure $6 a$ and $b$ ). Consistently, apoptosis was time- and dose-dependently induced by DAPT in concordance with caspase $3 / 7$ activation as determined by TUNEL staining (Figure $6 \mathrm{c}$ and $\mathrm{d}$ ). To examine the mechanism underlying IS-induced VSMCs apoptotic cell death, we examined the proapoptotic effect of IS on apoptosis in human aortic SMCs (Figure 6e-h). IS significantly activated caspase $3 / 7$ activity and increased TUNEL-positive cells dose- and time-dependently (Figure 6e-h). Considered together, 
these data indicate that IS induces apoptosis by decreasing Notch signaling.

\section{IS induces calcium deposition in aortic SMCs.}

To examine whether IS-induced apoptosis in aortic SMCs promotes vascular calcification, we examined the effects of IS on inorganic phosphorus-induced calcium deposition (Figure 7a and b). Calcium deposition in cultured human aortic SMCs was examined microscopically (Figure 7a) and measured quantitatively with correction for protein concentrations (Figure 7b). Exposure to IS increased calcium deposition significantly. Pharmacological Notch signal inhibition with DAPT also increased calcium deposition. On the other hand, ZVAD, a caspase 9-specific inhibitor, significantly reduced calcium deposition in both IS-treated and DAPT-treated human aortic SMCs. These results suggest that IS induces calcification of the aorta through apoptosis of aortic SMCs.
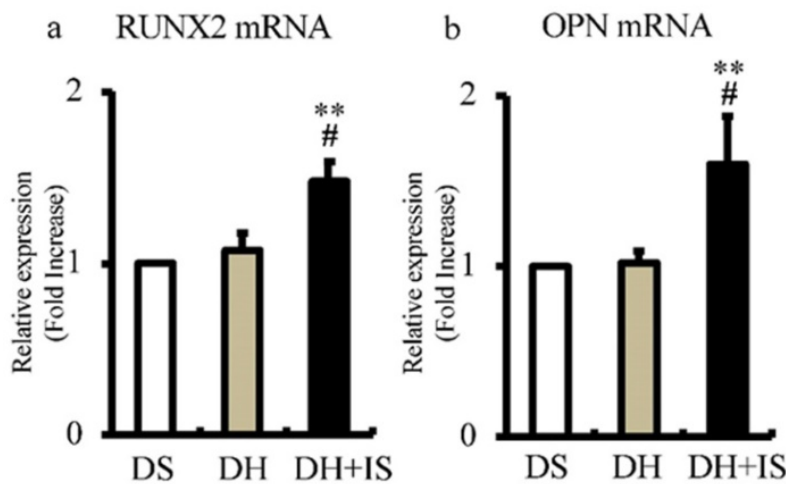

c OCN mRNA
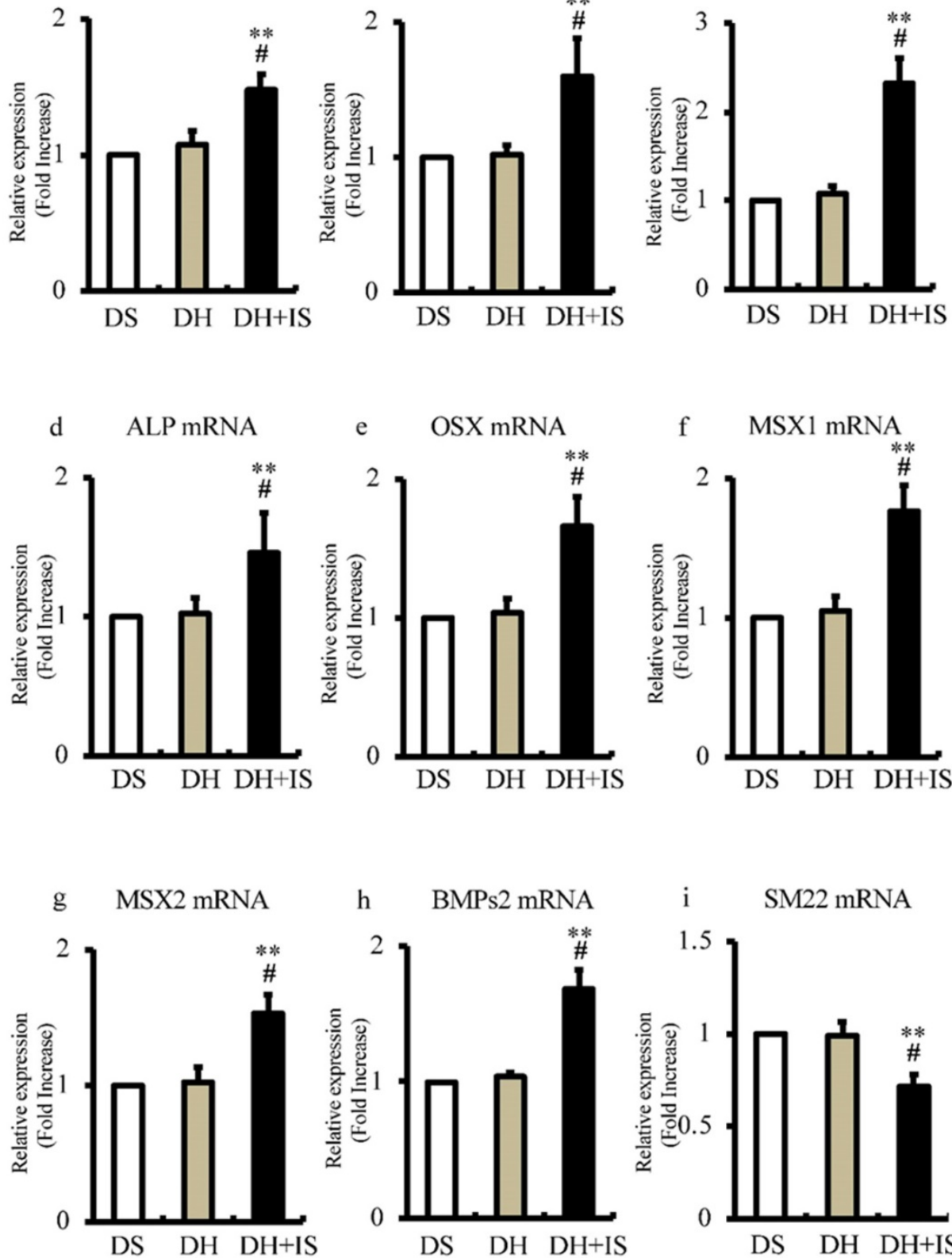


\section{Knockdown of Notch receptors induces transdifferentiating of VSMCs into osteoblast-like phenotype.}

To find out whether Notch1 or Notch3 is involved in alteration of osteoblast-like and smooth muscle cell-like transcriptional factors, single knockdown of Notch1 and 3 or double knockdown of Notch1/Notch3 of rat aortic SMCs was performed to analyze the expression of Notch related genes and these transcriptional factors with RT-PCR (Figure 7c-k). Knockdown of Notch1 and Notch3 showed no significant redundant interaction between Notch1 and Notch3 (Figure 7c and d). Knockdown of Notch1 suppressed Hes-1 and Hey-1 to upregulate Runx 2 and OPN (Figure 7e-g and i). Knockdown of Notch3 suppressed Hey-1, and increased BMPs2 and OCN (Figure $7 \mathrm{f}, \mathrm{h}$ and $\mathrm{j}$ ). On the other hand, single knockdown of both Notch1 and 3 suppressed the VSMC differentiation marker, SM22, respectively (Figure 7k). Synergic effects were observed in double knockdown of Notch1/Notch3 (Figure 7c-k). Thus, these dates indicate that inhibition of Notch1 and
Notch3 cooperatively induces osteogenic transcriptional factors and suppresses smooth muscle cell-like transcriptional factor, SM22.

\section{Discussion}

The novel findings of this study were that IS induced calcification of the aorta and reduced Notch signal activity in the central layer of the media layer as well as around the calcified lesions in hypertensive rats. The results also showed that the oral administration of IS for 30 weeks was followed by the appearance of calcified lesions in the media layer of both the aortic arch and coronary arteries (Figure 1) in the absence of any change in BP, renal function, and calcium-phosphorus product (Table 1). IS-induced decrease in Notch signal activity promoted osteogenic differentiation and apoptosis and ultimately the formation of calcified lesions. Immunohistochemical analysis demonstrated decreased expression of Notch1, Notch3, and Hes-1 in the central layer of the aortic media, which is a common site for calcification, and around calcified lesions (Figure 2).

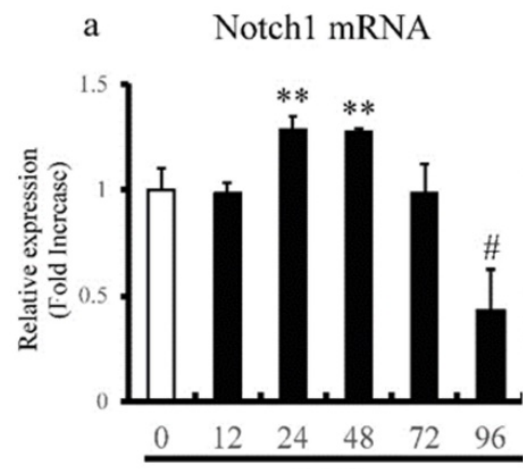

IS (h)

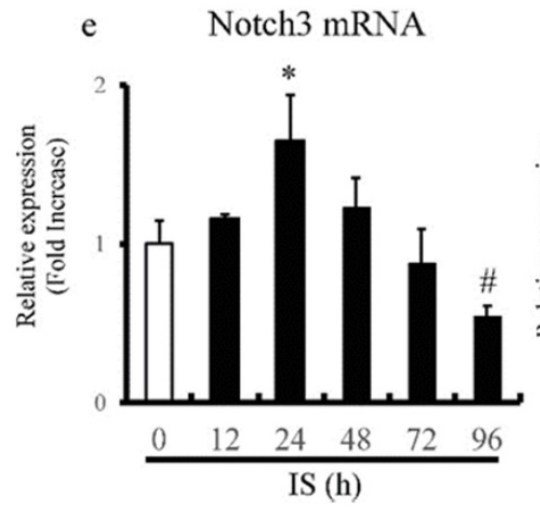

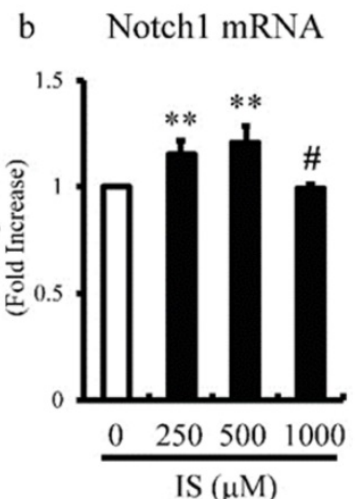

f $\quad$ Notch3 mRNA

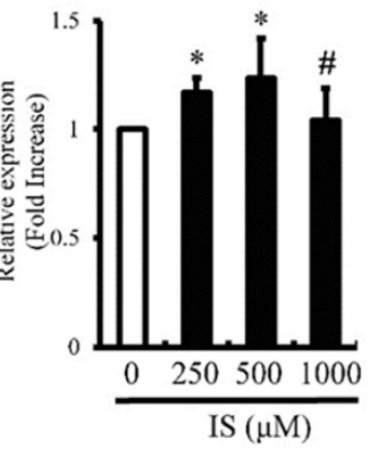

c

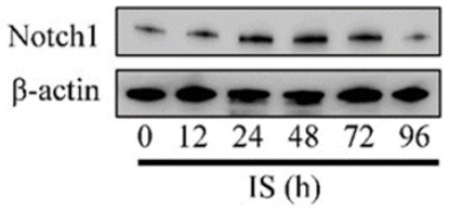

d

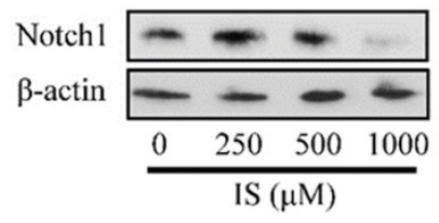

g

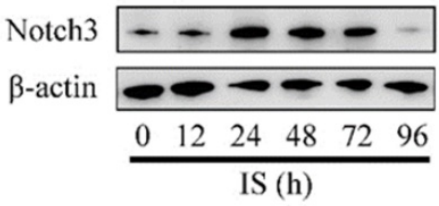

$\mathrm{h}$

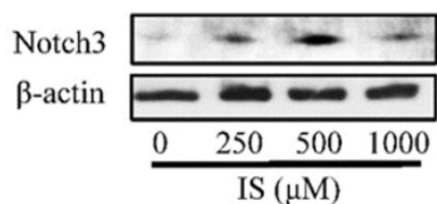

Figure 5. IS reduces Notch 1 and Notch3 expression in aortic smooth muscle cells (SMCs). Rat and human aortic SMCs were treated with IS for the indicated time intervals ( $a$ and $e$ ) and at the indicated doses ( $b$ and $f$ ). (a) IS increased the expression level of Notchl mRNA after 24- and 48-hr incubation but the level after incubation for 96 hrs was lower than non-treated control ( $* * p<0.002$ vs non-treated control, $\# p<0.0001$ vs non-treated control). (b) IS increased Notch $1 \mathrm{mRNA}$ expression when used at 250 and $500 \mu \mathrm{mol} / \mathrm{L}$, but the level in the presence of $1000 \mu \mathrm{mol} / \mathrm{L}$ was lower than at 250 and $500 \mu \mathrm{mol} / \mathrm{L}$ ( $* * \mathrm{p}<0.0002$ vs non-treated control, \#p<0.001 vs $500 \mu \mathrm{mol} / \mathrm{L}$ group). (e and $\mathrm{f}$ ) A similar trend was noted for the effect of duration of incubation with IS ( $* \mathrm{p}<0.01$ vs non-treated control, \#p $<0.01$ vs non-treated control) and dose of IS (*p<0.01 vs non-treated control, \#p<0.05 vs $500 \mu \mathrm{mol} / \mathrm{L}$ group) on Notch3 mRNA. Data are mean \pm SD ( $\mathrm{n}=4-6$ per group). (c, d, g, and h) Effects of duration of incubation and dose of IS on Notch1 and Notch3 protein levels in aortic SMCs cell lysates measured by western immunoblotting using anti-Notch1 and anti-Notch3 antibodies, respectively. IS decreased (c and d) Notch 1 and $(g$ and $h)$ Notch 3 protein levels after $96 \mathrm{~h}$ and at the concentration of $1000 \mu \mathrm{mol} / \mathrm{L}$. Representative data of 5 similar experiments. 
a

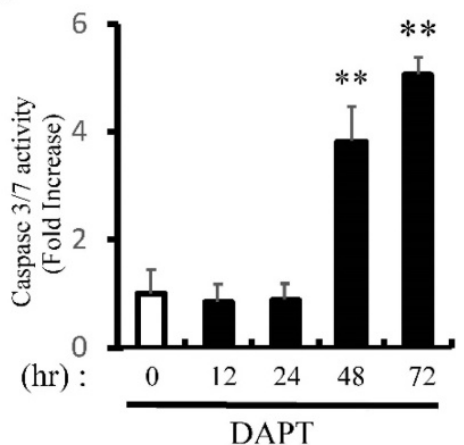

c

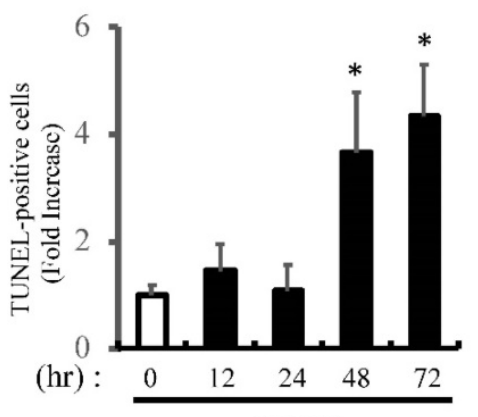

DAPT

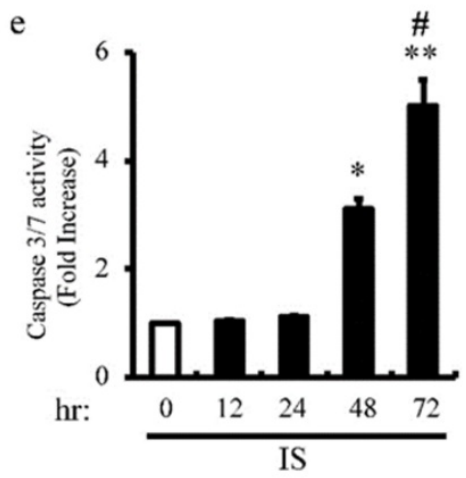

g

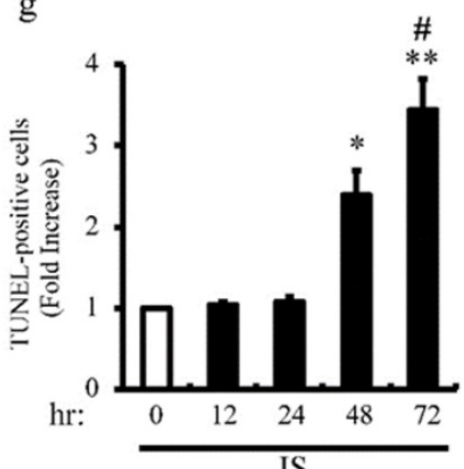

b

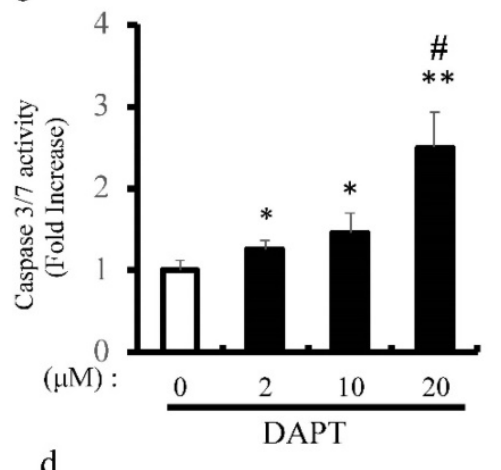

d
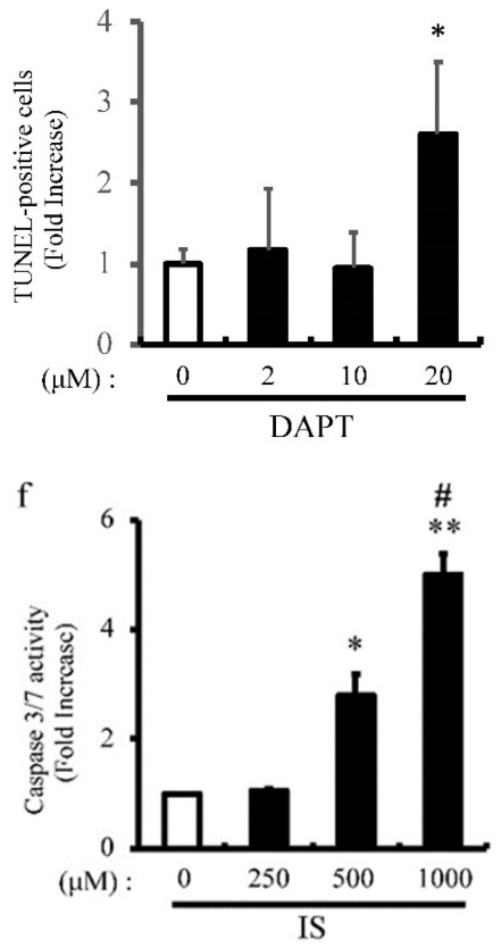

$\mathrm{h}$

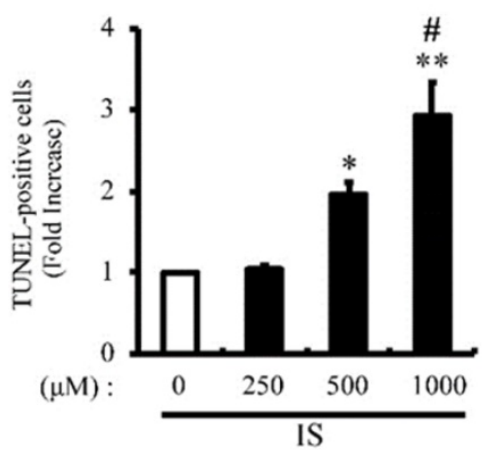

Figure 6. IS and DAPT induce apoptosis of aortic SMCs. Rat aortic SMCs were incubated with 0-20 $\mu \mathrm{mol} / \mathrm{L}$ of N-S-phenyl-glycine-t-butyl ester (DAPT), a Notch signal inhibitor, for the indicated time periods (0-72 hour). Cellular apoptosis was detected by caspase 3/7 activity assay and TUNEL assay according to the protocol provided by the manufacturer. (a) Quantitative analysis of caspase $3 / 7$ activity at different time points in rat aortic SMCs. ** $<0.0001$ vs non-treated control. Data are mean $\pm S D$ ( $n=6$ per group). (b) Quantitative analysis of caspase $3 / 7$ activity at different dose in rat aortic SMCs. ${ }^{*}<<0.01$, **p $<0.0001$ vs non-treated control, \#p $<0.001$ vs $10 \mu M$ group. Data are mean $\pm S D$ $(\mathrm{n}=6$ per group). (c) Quantitative analysis of TUNEL-positive cells at different time points in rat aortic SMCs. * $\mathrm{p}<0.001$ vs non treated control. Data are mean $\pm S D(n=6$ per group). (d) Quantitative analysis of TUNEL-positive cells at different dose in rat aortic SMCs. *p<0.01 vs non-treated control. Data are mean \pm SD ( $n=6$ per group). Human aortic SMCs were incubated with 0-1000 $\mu \mathrm{mol} / \mathrm{L}$ of IS for the indicated time periods ( $0-72$ hour). (e) Quantitative analysis of caspase $3 / 7$ activity at different time points in human aortic SMCs. ${ }^{*}<0.001, * * p<0.0001$ vs non-treated control, \#p $<0.0001$ vs $48 \mathrm{hr}$ group. Data are mean $\pm S D$ ( $n=6$ per group). (f) Quantitative analysis of caspase $3 / 7$ activity at different dose in human aortic SMCs. ${ }_{p}<0.003$, ** $p<0.0001$ vs non-treated control, \#p<0.0001 vs $500 \mu M$ group. Data are mean $\pm S D(n=6$ per group). (g) Quantitative analysis of TUNEL-positive cells at different time points in human aortic SMCs. * $\mathrm{p}<0.001$, **p $<0.0001$ vs non-treated control, \#p<0.0003 vs $48 \mathrm{hr}$ group. Data are mean $\pm S D$ ( $n=6$ per group). (h) Quantitative analysis of TUNEL-positive cells at different doses in human aortic SMCs. ${ }^{p} p<0.0004,{ }^{*} p<0.0001$ vs non treated control, \#p $<0.004$ vs $500 \mu M$ group. Data are mean $\pm S D(n=6$ per group). 
Quantitative RT-PCR showed IS downregulated the expression of Notch ligands (Jagged1 and DLL4), Notch receptors (Notch1 and Notch3), and downstream transcriptional factors (Hes-1 and Hey-1) (Figure 3). Concordant with the decrease in Notch activity, IS also upregulated the expression of several osteogenic markers in the aorta and downregulated the VSMC differentiation marker SM22 in hypertensive rats (Figure 4). Notch signal inhibition promotes apoptosis [8] and apoptotic bodies from VSMCs promote crystallization of calcium and phosphate in preparation for mineralization [13]. IS reduced Notch signaling in cultured aortic SMCs time- and dose-dependently (Figure 5). Coupled with the downregulation of Notch signaling, IS and pharmacological inhibition of Notch signaling similarly promoted apoptosis of aortic SMCs in the same manner (Figure 6). IS-induced calcification in cultured aortic SMCs was significantly suppressed by ZVAD, a caspase inhibitor (Figure 7). Finally, knockdown of Notch1 and Notch3 cooperatively increased the expression of osteoblast transcriptional markers and decreased VSMC differentiation marker, SM22.
Previous studies reported that administration of IS in hypertensive rats results in various pathological changes including medial calcification in both the aorta and coronary arteries, which is known in human as Mönckeberg's sclerosis [24]. Mönckeberg medial sclerosis is specifically localized in both small transitional arteries, such as coronary arteries and large elastic-type arteries, such as the aorta [24] [25], and it is frequently associated with accumulation of IS and severity of CKD [25]. Animal models of Mönckeberg's sclerosis have been hardly discussed, but the IS-treated hypertensive rats is a suitable model to investigate the underlying pathophysiology. In patients with CKD, accumulation of uremic toxins (particularly inorganic phosphate, IS, advanced glycation end-products and inflammatory cytokines) is responsible for the high prevalence of vascular calcification [1]. In this model, IS accumulation results in dysfunction of multiple cell signaling pathways [12]. Notch signal is one of the most notable candidate signal affected by IS based on our finding of IS-induced downregulation of Notch-related molecules in the aorta, especially in the calcified lesions and the central layer of the aortic media, which is a common lesion of vascular calcification.
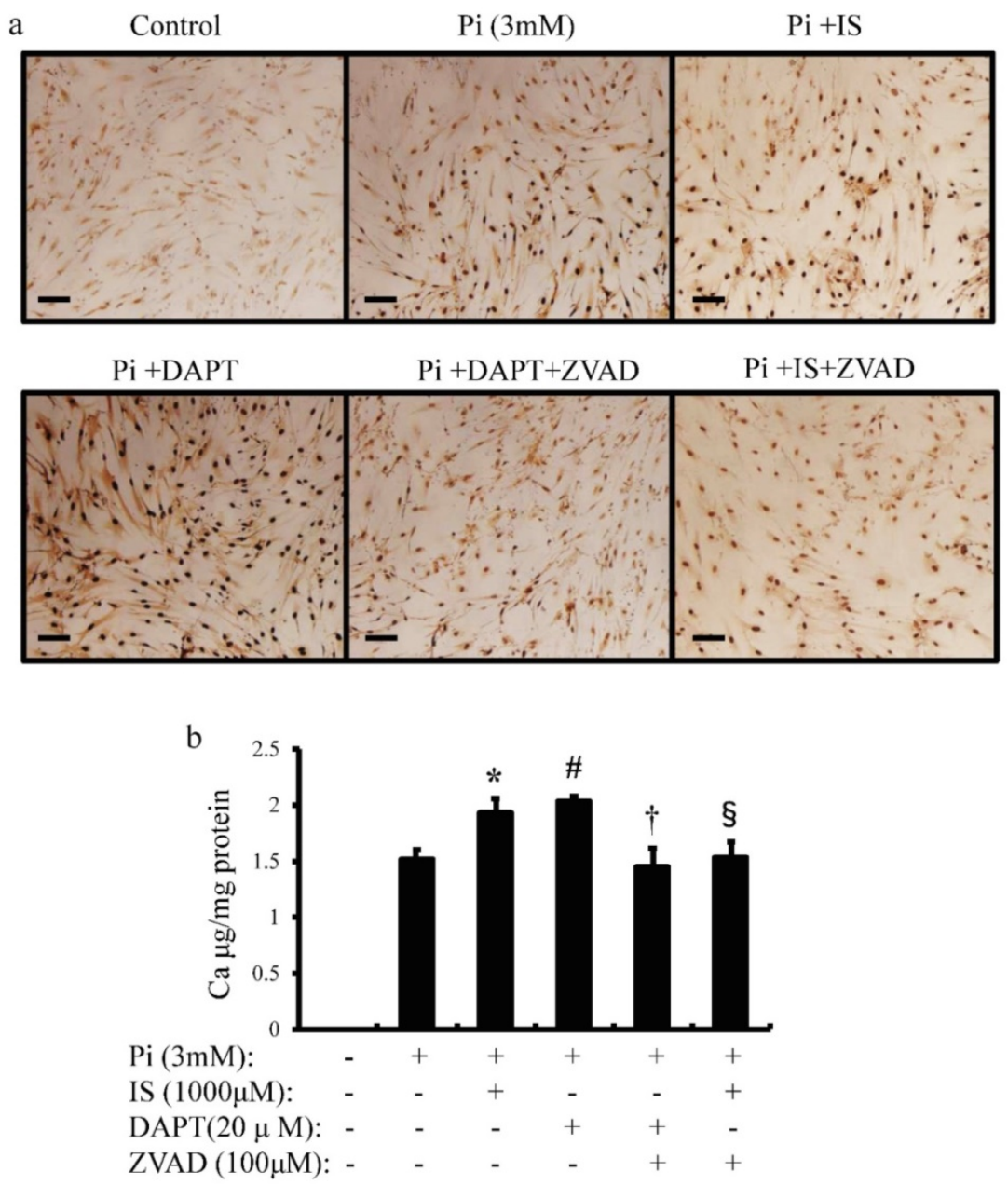
Notch1 mRNA

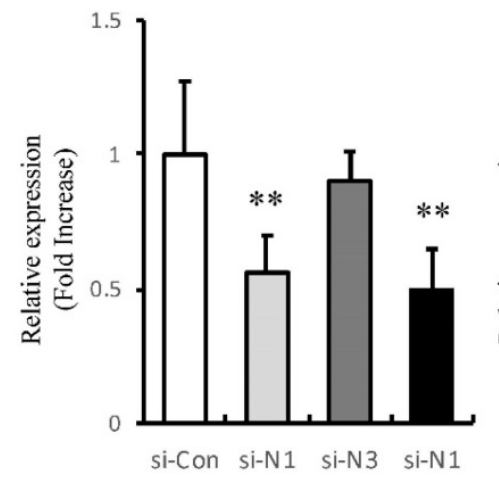

si-N3 d Notch3 mRNA

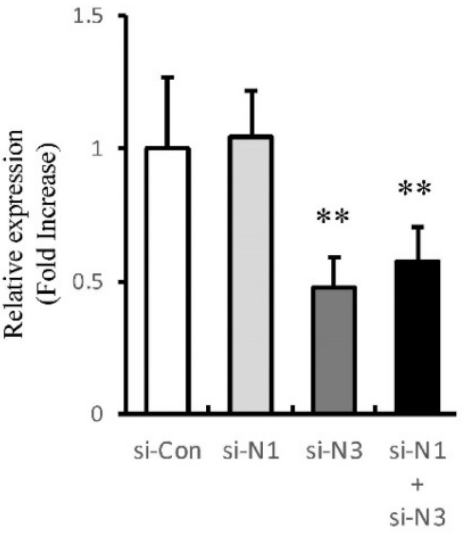

e

Hes-1 mRNA

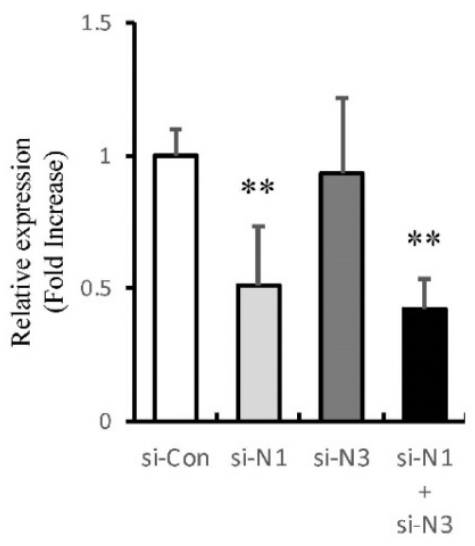

$\mathrm{h}$

BMPS2 mRNA
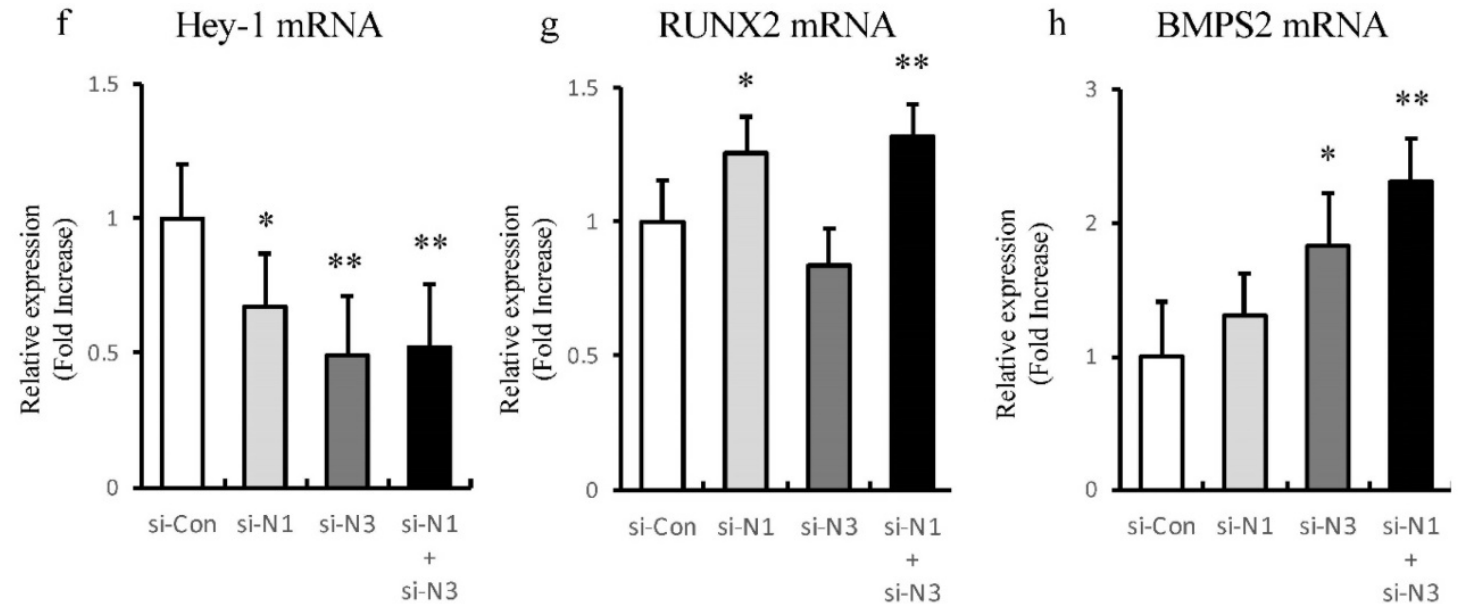

i

OPN mRNA

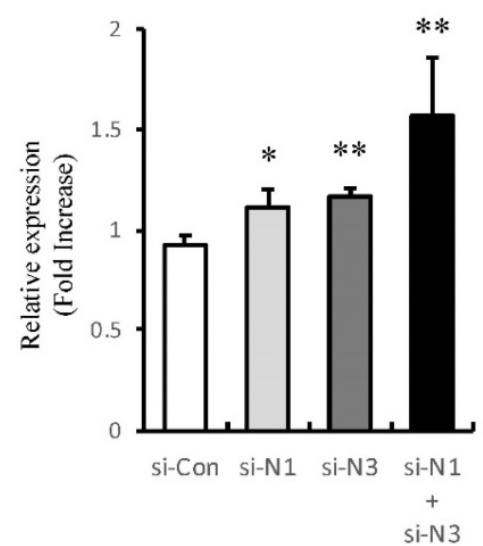

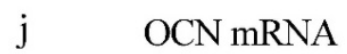

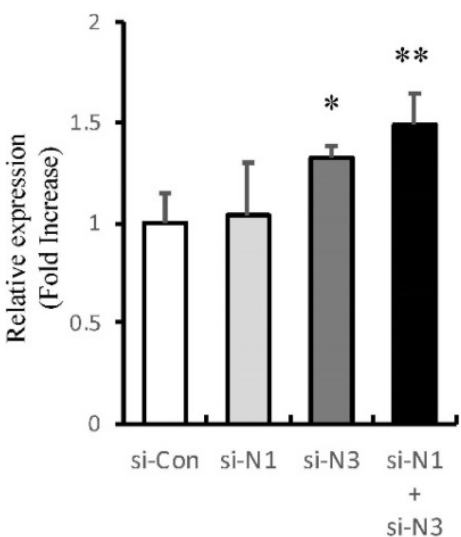

k

SM22 mRNA

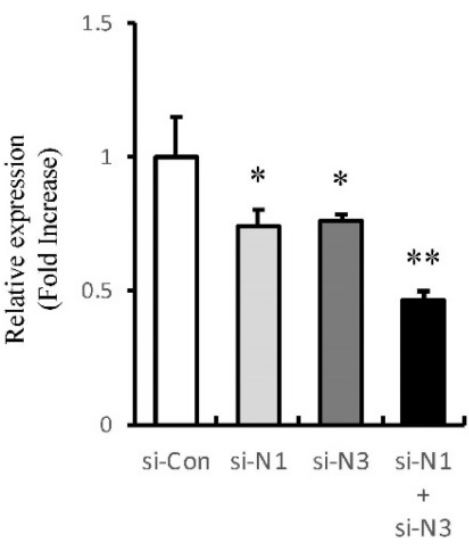

Figure 7. IS induces cellular calcium deposition in aortic SMCs. Calcium deposition in human aortic SMCs was induced by inorganic phosphate (3 mM). Cells were seeded at a density of $2 \times 105$ cells/well on 12 -well culture plate in D-MEM containing $10 \%$ FBS for 48 hrs. Cells were pre-incubated with DAPT (20 $\mu$ M) and ZVAD (100 $\mu$ M) for $1 \mathrm{hr}$, then stimulated with $\mathrm{Pi}(3 \mathrm{mM})$ or IS $(1000 \mu \mathrm{M})$ for $72 \mathrm{hrs}$. Absorbance was measured at $570 \sim 650 \mathrm{~nm}$ using a microplate reader. (a) Representative images showing calcium deposition in IS- or Pi-treated human aortic SMCs $(\times 200$ magnification, bar $=50 \mu \mathrm{m})$. (b) Quantitative analysis of calcium deposition in IS- and Pi-treated human aortic SMCs. Data are mean $\pm S D$ ( $n=6$ per group). ${ }^{*} p<0.009$ vs $\mathrm{Pi}(3 \mathrm{mM})$ group, $\# \mathrm{p}<0.0008 \mathrm{vs} \mathrm{Pi}(3 \mathrm{mM})$ group, $\dagger \mathrm{p}<0.0059$ vs DAPT-treated group, $\S \mathrm{p}<0.009$ vs IS-treated group. Expression levels of Notch-related and osteogenic-related mRNA with single knockdown of Notchl and 3 or double knockdown of Notch1/Notch3 in rat aortic SMCs was analyzed by quantitative RT-PCR. Data are mean \pm SD ( $n=6-8$ per group). (c) Notchl (**p<0.01 vs si-control group) (d) Notch3 (**p<0.01 vs si-control group) (e) Hes-1 (**p<0.01 vs si-control group) (f) Hey-1 (*p<0.05 vs si-control group, ${ }^{* *} p<0.01$ vs si-control group) (g) Run $\times 2$ (*p<0.05 vs si-control group, ** $p<0.01$ vs si-control group) (h) BMPS2 (*p<0.05 vs si-control group, ${ }^{* *} \mathrm{p}<0.01$ vs si-control group) (i) osteopontin (OPN) $\left({ }^{*} \mathrm{p}<0.05\right.$ vs si-control group, $* *$ p $<0.01$ vs si-control group) (j) osteocalcin (OCN) $(* \mathrm{p}<0.05$ vs si-control group, ${ }^{* *} \mathrm{p}<0.01$ vs si-control group), and (k) SM22 (*p<0.05 vs si-control group, ${ }^{* *} \mathrm{p}<0.01$ vs si-control group).

Little is known about the mechanisms of Notch downregulation. It is possible that IS-induced downregulation of Notch reflects abnormal response to tissue hypoxia since reduced Notch signaling was observed in the central layer of the aortic media, which is a common lesion in hypoxic damage [26]. In 
this regard, IS is reported to activate aryl hydrocarbon receptor (AhR), which suppresses nuclear accumulation of the hypoxia-inducible factor (HIF)-a-AhR nuclear translocator (ARNT) complex, accompanied by an increase in the AhR-ARNT complex in the nucleus, resulting in failure of HIF-a-dependent response to hypoxia [27]. Interestingly, Notch signal is ordinarily activated under hypoxic conditions [28]. HIF-a interacts with the NICD and stabilizes this complex formation to upregulate the Notch signal pathway [28].

Since HIF-a is required for hypoxia-induced Notch signal activation, IS-induced disturbance in HIF-a pathway could suppress Notch signaling. Notch signal activation triggers a positive feed-back mechanism to produce Notch-related molecules [6]. Meanwhile, pharmacological inhibition of enzymatic cleavage with DAPT was reported to downregulate Notch-related molecules [6]. A decrease in Notch signal activity per se would reduce the expression of Notch-related molecules. Thus, IS-induced abnormal response to hypoxia would initiate decreased Notch signal activity itself to provide the negative feedback.

Osteogenic differentiation is an important process in the Mönckeberg medial calcific sclerosis [1, 25]. Examination of calcified human valves has demonstrated increased expression of various osteogenic markers, such as Runx2 [29]. In the present study, we also showed overexpression of various osteogenic markers and underexpression of the VSMC differentiation marker SM22, with the observed downregulation of Notch activity in the aortas of IS-treated hypertensive rats (Figure 4). Notch signal plays critical roles in VSMC differentiation into mature and osteoblastic phenotypes [16]. Interestingly, IS suppressed expression of Notch1 and Notch3, followed by a transient activation (Figure 5). To examine whether decline in Notch signal enhances osteogenic property and dedifferentiation of VSMCs, knockdown study of Notch1 and 3 was performed (Figure 7). No redundancy was observed between Notch1 and Notch3. In the downstream of Notch1 inhibition, increase in osteogenic transcription factors, Runx2 and OPN was observed [30] [31]. The mechanisms how Notch3 signal alters osteogenic transcription factors have been unclear. However, knockdown of Notch3 upregulated BMPs2 and OCN as previously shown [32]. It has been reported that Notch pathway constitutes an instructive signal for SMC differentiation through an RBP-JK-dependent mechanism [33]. Conversely, single knockdown of both Notch1 and 3 respectively suppressed the VSMC differentiation marker SM22. Synergically double knockdown of Notch1/3 strongly induced osteogenic transcription factors and VSMC dedifferentiation.
Thus, Notch signal suppression with IS induces disarrangement of transcriptional factors to promote osteogenic property.

During development, Notch ligand, Jagged1, which is derived from endothelial cells, activates Notch signaling in VSMCs to promote VSMC maturation [34]. In contrast, a decrease in Notch signal is reported to play a role in osteogenic differentiation [29]. Garg et al. [17] showed that Notch1 signaling suppresses Runx2 signaling via interaction of Runx 2 with Hrt family proteins, such as Hes-1 and Hey-1, and that human haploinsufficient Notch1 mutation promotes osteogenic differentiation and calcium deposition in aortic valve interstitial cells. As shown above, endothelial cells play critical roles in the regulation of vascular Notch signaling [34]. IS promotes endothelial dysfunction through the induction of oxidative stress and progressive inflammatory process [12]. Endothelial nitric oxide (NO)-knockout mice model showed that endothelial dysfunction was associated with reduced Notch signal activity in valve interstitial cells and activation of Runx2 signal [35]. Thus IS-induced vascular injury seems to attenuate vascular Notch signal to promote the Mönckeberg medial calcific sclerosis.

The present study showed that IS-induced Notch downregulation was associated with enhanced apoptosis of human aortic SMCs, an important process in vascular calcification. Previous studies stressed the importance of Notch signal in cell survival under the conditions of cell stress and vascular injury [8], and demonstrated that pharmacological inhibition of Notch signaling and Notch1 haploinsufficiency increase apoptosis. Other studies showed that free radicals induced by IS in VSMCs activate nuclear factor kappa-B (NF-kB) and p53 pathways to promote apoptosis [36]. Others reported that Notch1 signaling protects cells against NF-kB- and p53-induced apoptosis through the activation of Akt pathway [37]. The NICD, which is cleaved out and released into cytoplasm, binds to the mammalian target of rapamycin complex (mTORC) to activate AKT signaling [37]. Similarly, the Notch target gene, Hes-1, reduces the expression levels of phosphatase and tensin homolog (PTEN) to disinhibit the PI3K-AKT-mTORC pathway and promote cell survival. Thus, Notch signal is indispensable in protection against IS-induced proapoptotic stimuli.

In patients with CKD, high IS plasma levels are involved in the progression of atherosclerosis and aortic calcification [3, 38]. Aortic calcification and Mönckeberg's arteriosclerosis are high risks for cardiovascular morbidity and mortality based on the high potential of cardiovascular events in patients with CKD [2, 39]. Thus, IS-induced arterial 
calcification is a potentially suitable therapeutic target for the prevention of cardiovascular events. Furthermore, since the decrease in Notch signaling is involved in IS-induced aortic calcification, Notch signal activators could be potentially useful therapeutically. We showed previously that pitavastatin activates endothelial Notch1 through Akt-dependent stimulation of $\gamma$-secretase [7]. Endothelial Notch activators, such as pitavastatin, might maintain VSMC Notch signaling against IS-induced disturbance of Notch signal pathway.

\section{Acknowledgments}

We thank Dr. F.G. Issa (www.word-medex .com.au) for the careful reading and editing of this manuscript. Work in the group led by K.T. is supported by SENSHIN Medical Research Foundation (Japan), and a Grant-in-Aid for Scientific Research from the Japan Society for the Promotion of Research (JSPS) (Kakenhi \#18H02729). M.Y. is a JSPS doctoral fellow (JSPS KAKENHI grant \#15J00397 for overseas researchers).

\section{Ethics approval and consent to participate}

The Animal Care Committee of Kureha Biomedical Research Laboratories approved the animal studies described here (IRB approval number: A15-081). All experiments were conducted according to the Guiding Principles for the Care and Use of Laboratory Animals of the Japanese Pharmacological Society.

\section{Competing Interests}

S.G. is employed by Kureha Co. All other authors have no competing interests to declare. Kureha Co had no role in the design of the study; in the collection, analyses, or interpretation of data; in the writing of the manuscript, or in the decision to publish the results.

\section{References}

1. Henaut L, Mary A, Chillon JM, Kamel S, Massy ZA. The Impact of Uremic Toxins on Vascular Smooth Muscle Cell Function. Toxins. 2018; 10.

2. Furusawa K, Takeshita K, Suzuki S, Tatami Y, Morimoto R, Okumura T, et al. Assessment of abdominal aortic calcification by computed tomography for prediction of latent left ventricular stiffness and future cardiovascular risk in pre-dialysis patients with chronic kidney disease: A single center cross-sectional study. International journal of medical sciences. 2019; 16: 939-48.

3. Sato B, Yoshikawa D, Ishii H, Kikuchi R, Arima T, Takeshita K, et al. Indoxyl sulfate, a uremic toxin, and carotid intima-media thickness in patients with coronary artery disease. International journal of cardiology. 2013; 163: 214-6.

4. Baeten JT, Lilly B. Notch Signaling in Vascular Smooth Muscle Cells. Advances in pharmacology. 2017; 78: 351-82.

5. Radtke F, Wilson A, Mancini SJ, MacDonald HR. Notch regulation of lymphocyte development and function. Nature immunology. 2004; 5: 247-53.
6. Takeshita K, Satoh M, Ii M, Silver M, Limbourg FP, Mukai Y, et al. Critical role of endothelial Notch1 signaling in postnatal angiogenesis. Circulation research. 2007; 100: 70-8.

7. Kikuchi R, Takeshita K, Uchida Y, Kondo M, Cheng XW, Nakayama T, et al. Pitavastatin-induced angiogenesis and arteriogenesis is mediated by Notch1 in a murine hindlimb ischemia model without induction of VEGF. Laboratory investigation; a journal of technical methods and pathology. 2011; 91: 691-703.

8. Li Y, Takeshita K, Liu PY, Satoh M, Oyama N, Mukai Y, et al. Smooth muscle Notch1 mediates neointimal formation after vascular injury. Circulation. 2009; 119: 2686-92.

9. Fischer A, Schumacher N, Maier M, Sendtner M, Gessler M. The Notch target genes Hey1 and Hey2 are required for embryonic vascular development. Genes \& development. 2004; 18: 901-11.

10. Tamai H, Kobayashi M, Takeshita K, Kodama A, Banno H, Narita H, et al. Possible involvement of Notch signaling in the pathogenesis of Buerger's disease. Surgery today. 2014; 44: 307-13.

11. Shang Y, Smith $\mathrm{S}, \mathrm{Hu} X$. Role of Notch signaling in regulating innate immunity and inflammation in health and disease. Protein \& cell. 2016; 7: 159-74.

12. Niwa T. Targeting protein-bound uremic toxins in chronic kidney disease. Expert opinion on therapeutic targets. 2013; 17: 1287-301.

13. Leopold JA. Vascular calcification: Mechanisms of vascular smooth muscle cell calcification. Trends in cardiovascular medicine. 2015; 25: 267-74.

14. Zamurovic N, Cappellen D, Rohner D, Susa M. Coordinated activation of notch, Wnt, and transforming growth factor-beta signaling pathways in bone morphogenic protein 2-induced osteogenesis. Notch target gene Hey1 inhibits mineralization and Runx2 transcriptional activity. The Journal of biological chemistry. 2004; 279: 37704-15.

15. Tang Z, Wei J, Yu Y, Zhang J, Liu L, Tang W, et al. gamma-Secretase inhibitor reverts the Notch signaling attenuation of osteogenic differentiation in aged bone marrow mesenchymal stem cells. Cell biology international. 2016; 40: 439-47.

16. Harrison OJ, Visan AC, Moorjani N, Modi A, Salhiyyah K, Torrens C, et al. Defective NOTCH signaling drives increased vascular smooth muscle cell apoptosis and contractile differentiation in bicuspid aortic valve aortopathy: A review of the evidence and future directions. Trends in cardiovascular medicine. 2019; 29: 61-8.

17. Garg V, Muth AN, Ransom JF, Schluterman MK, Barnes R, King IN, et al. Mutations in NOTCH1 cause aortic valve disease. Nature. 2005; 437: 270-4.

18. Adijiang A, Goto S, Uramoto S, Nishijima F, Niwa T. Indoxyl sulphate promotes aortic calcification with expression of osteoblast-specific proteins in hypertensive rats. Nephrology, dialysis, transplantation : official publication of the European Dialysis and Transplant Association - European Renal Association. 2008; 23: 1892-901.

19. Niwa T, Takeda N, Tatematsu A, Maeda K. Accumulation of indoxyl sulfate, an inhibitor of drug-binding, in uremic serum as demonstrated by internal-surface reversed-phase liquid chromatography. Clinical chemistry. 1988; 34: 2264-7.

20. Yisireyili M, Takeshita K, Hayashi M, Wu H, Uchida Y, Yamamoto K, et al. Dipeptidyl peptidase- IV inhibitor alogliptin improves stress-induced insulin resistance and prothrombotic state in a murine model. Psychoneuroendocrinology. 2016; 73: 186-95.

21. Aoyama T, Takeshita K, Kikuchi R, Yamamoto K, Cheng XW, Liao JK, et al. gamma-Secretase inhibitor reduces diet-induced atherosclerosis in apolipoprotein E-deficient mice. Biochemical and biophysical research communications. 2009; 383: 216-21.

22. Uchida Y, Takeshita K, Yamamoto K, Kikuchi R, Nakayama T, Nomura $\mathrm{M}$, et al. Stress augments insulin resistance and prothrombotic state: role of visceral adipose-derived monocyte chemoattractant protein-1. Diabetes. 2012; 61: 1552-61.

23. Chen NX, O'Neill KD, Duan D, Moe SM. Phosphorus and uremic serum up-regulate osteopontin expression in vascular smooth muscle cells. Kidney international. 2002; 62: 1724-31.

24. McCullough PA, Agrawal V, Danielewicz E, Abela GS. Accelerated atherosclerotic calcification and Monckeberg's sclerosis: a continuum of advanced vascular pathology in chronic kidney disease. Clinical journal of the American Society of Nephrology : CJASN. 2008; 3: 1585-98.

25. Lanzer P, Boehm M, Sorribas V, Thiriet M, Janzen J, Zeller T, et al. Medial vascular calcification revisited: review and perspectives. European heart journal. 2014; 35: 1515-25.

26. Billaud M, Hill JC, Richards TD, Gleason TG, Phillippi JA. Medial Hypoxia and Adventitial Vasa Vasorum Remodeling in Human Ascending Aortic Aneurysm. Frontiers in cardiovascular medicine. 2018; 5: 124

27. Asai H, Hirata J, Hirano A, Hirai K, Seki S, Watanabe-Akanuma M. Activation of aryl hydrocarbon receptor mediates suppression of 
hypoxia-inducible factor-dependent erythropoietin expression by indoxyl sulfate. American journal of physiology Cell physiology. 2016; 310: $\mathrm{C} 142-50$

28. Landor SK, Lendahl U. The interplay between the cellular hypoxic response and Notch signaling. Experimental cell research. 2017; 356: 146-51.

29. Garg V. Notch Signaling in Aortic Valve Development and Disease. In: Nakanishi T, Markwald RR, Baldwin HS, Keller BB, Srivastava D, Yamagishi H, editors. Etiology and Morphogenesis of Congenital Heart Disease: From Gene Function and Cellular Interaction to Morphology. Tokyo; 2016. p. 371-6

30. Hilton MJ, Tu X, Wu X, Bai S, Zhao H, Kobayashi T, et al. Notch signaling maintains bone marrow mesenchymal progenitors by suppressing osteoblast differentiation. Nature medicine. 2008; 14: 306-14.

31. Yao XX, Lu JB, Ye ZD, Zheng L, Wang Q, Lin ZQ, et al. Hairy/enhancer of Split Homologue-1 Suppresses Vascular Endothelial Growth Factor-induced Angiogenesis via Downregulation of Osteopontin Expression. 2017; 7: 898.

32. Wang H, Jiang Z, Zhang J, Xie Z, Wang Y, Yang G. Enhanced osteogenic differentiation of rat bone marrow mesenchymal stem cells on titanium substrates by inhibiting Notch3. Archives of oral biology. 2017; 80:34-40.

33. Doi $H$, Iso $T$, Sato $H$, Yamazaki $M$, Matsui $H$, Tanaka $T$, et al. Jagged1-selective notch signaling induces smooth muscle differentiation via a RBP-Jkappa-dependent pathway. The journal of biological chemistry. 2006; 281: 28555-64.

34. High FA, Lu MM, Pear WS, Loomes KM, Kaestner KH, Epstein JA. Endothelial expression of the Notch ligand Jagged1 is required for vascular smooth muscle development. Proceedings of the National Academy of Sciences of the United States of America. 2008; 105: 1955-9.

35. Bosse K, Hans CP, Zhao N, Koenig SN, Huang N, Guggilam A, et al. Endothelial nitric oxide signaling regulates Notch1 in aortic valve disease. Journal of molecular and cellular cardiology. 2013; 60: 27-35.

36. Niwa T, Shimizu H. Indoxyl sulfate induces nephrovascular senescence. Journal of renal nutrition : the official journal of the Council on Renal Nutrition of the National Kidney Foundation. 2012; 22: 102-6.

37. Zeng C, Xing R, Liu J, Xing F. Role of CSL-dependent and independent Notch signaling pathways in cell apoptosis. Apoptosis : an international journal on programmed cell death. 2016; 21: 1-12.

38. Gao H, Liu S. Role of uremic toxin indoxyl sulfate in the progression of cardiovascular disease. Life sciences. 2017; 185: 23-9.

39. Lehto S, Niskanen L, Suhonen M, Ronnemaa T, Laakso M. Medial artery calcification. A neglected harbinger of cardiovascular complications in non-insulin-dependent diabetes mellitus. Arteriosclerosis, thrombosis, and vascular biology. 1996; 16: 978-83. 